\title{
LA CIERVA Y LA CUESTION SOCIAL: 1907-1909
}

\author{
Concepción Fernández-Cordero Azorín
}

\begin{abstract}
a) LAS RESPONSABILIDADES DE LA CIERVA, MINISTRO DE LA GOBERNACION, EN LA REPRESION DE LA «SEMANA TRAGICA» DE BARCELONA: 1909
\end{abstract}

"La ciudad de Barcelona es... una ciudad substancialmente revolucionaria; lo ha sido siempre... Pero en Barcelona, cuando la semana de julio, esas gentes que padecen, o tienen, o disfrutan ese espíritu revolucionario, vieron la revolución cara a cara, y la vieron en el más repugnante de sus aspectos, y en Barcelona, en aquellos días... yo pude apreciar un deseo, por todo el mundo sentido, de gubernamentalizarse: la gran masa de ciudadanos de Barcelona había tomado horror a la revolución, deseaba acercarse a la autoridad». (Francisco de Asís CAMBO. El moment politic, 4 de noviembre de 1909).

«En el incendio de los conventos, como se ha supuesto, los socialistas no han tomado parte alguna. Si se hubieran encontrado en condiciones de realizar ciertos actos, nuestros camaradas los hubieran realizado más ventajoso y más significativos para nuestra causa... El partido socialista y los elementos obreros que han protestado son los únicos cuya acción tuvo por característica oponerse resueltamente a la guerra» (de Marruecos). (Pablo IGLESIAS. Carta a CLERBAUT, publicada en Le Peuple, de Bruselas, 22 de agosto de 1909, fechada en 17 anterior).

Resulta natural que fuese Barcelona la adelantada en el planteamiento de la subversión social, aunque con vestigios de formas todavía románticas o decimonónicas (nihilistas, anarquistas). El mismo Francisco FERRER GUARDIA en 1906 (Barcelona, 31 de mayo) escribió a José NACKENS: 
"Si deseamos una revolución y queremos que alguien la personifique, ese alguien es Lerroux. Hoy es él quien está en lo cierto, quien quiere hacer y quien hallará otros que le sigan, militares y paisanos. ¿Me equivoco? ¿Habrá que desandar luego lo andado? No importa. Volveremos a empezar. Naturalmente que no estoy conforme con Lerroux en muchas cosas; pero sí considero que él es el más significạdo y y él me dirigí y con él me abracé. Dispénseme» (1).

Ahora bien, que Barcelona fuese el lugar donde la catarsis mostró toda su pujanza, por estar el terreno especialmente abonado, no quiere decir que fuera el único escenario de la chispa insurreccional. El Gobierno, en una nota oficiosa y convenida por la autoridad militar, habló de los intentos de Logroño, Bilbao, Zaragoza, Alcoy y muchos más, con su ineludible cortejo de muertos y heridos. Las cifras, que conviene cotejar, debieron ser escamoteadas a la opinión pública con tal de minimizar lo acontecido. Hubo atentados contra las vías férreas, que creemos que indistintamente corrieron a cargo de los insurgentes y de los elementos gubernamentales (éstos con el propósito de dejar aislada a Cataluña). La energía de LA CIERVA cortando las comunicaciones telefónicas y telegráficas con el Principado y la primera versión de que el movimiento tenía carácter cantonal frenaron muchos ímpetus - a cuyo receso ayudó en Barcelona la secuela de atentados, robos, actos de pillaje, desaparición de títulos-resguardos de la Bolsa o de la Deuda Pública. etc. - . Los elementos más moderados retrocedieron de sus postulados primeros ante sus consecuencias prácticas (es sintomática la actitud de Joan MARAGALL, resumida en su bellísima composición poética en catalán "La iglesia quemada»).

Para José BENET el balance de la Semana Sangrienta arroja la impresionante cifra de 42 edificios religiosos destruidos, 78 muertos y más de 150 heridos (2). Según la «nota convenida y aprobada por la autoridad militar», facilitada por CIERVA a la prensa, las bajas ascendian en el Ejército a tres muertos y 27 heridos; en los paisanos, en el cementerio del Sudoeste hasta el día 30 de julio fueron enterrados 75 cadáveres, y

(1) Carta reproducida en "El Mercantil Valenciano», lunes 27 de Mayo de 1907. Fue escrita el mismo dia de las nupcias regias. Sobre la "Semana Trágica» de Barcelona, además de la bibliografia existente: FERNANDEZ-CORDERO AZORIN, Concepción. "La proyección francesa sobre la Semana Trágica de Barcelona». Coloquios Franco-españoles de la Universidad de Pau. Marzo de 1980. Y: «Algunas reflexiones sobre la Semana Trágica de Barcelona». Vol. III, pág. 157 y ss. Homenaje a M. TUÑNON DE LARA. Santander, Julio de 1981.

(2) «Maragall y la Semana Trágica». 
126 heridos ingresados en hospitales «habiendo quedado gran número de ellos ocultos en las casas particulares para su curación» (3).

Según Salvador CANALS (4), fueron asesinadas unas 15 personas, de ellas, 6 religiosos; 68 templos incendiados y saqueados total o parcialmente. En la lucha callejera hubo 104 muertos, de los cuales correspondieron 8 a la fuerza pública, y 296 heridos graves de los que la mitad eran soldados o guardias. Se construyeron 130 barricadas levantando para ello 2.600 metros cuadrados de pavimento de las calles. Se arrancarón 2.000 faroles de alumbrado público. Se perdieron bienes, joyas, dinero y centenares de títulos de valores mobiliarios, cuya lista fue posteriormente publicada por el Colegio de Agentes de Cambio y Bolsa de Barcelona.

La única línea de Barcelona que no quedó cortada con el resto de España fue el cable de Palma de Mallorca que enlazaba con el de Menorca y que amarraba en Ibi; CIERVA se apoderó del amarre de Ibi, prohibiendo toda comunicación, salvo la del Ministerio de Guerra; quedó custodiada por un destacamento de la Guardia Civil y los funcionarios de Comunicaciones de Barcelona supieron guardar el secreto (5).

Esto, en lo que se refiere a las «víctimas de la revolución». Las de la "reacción» Pueden cuantificarse como sigue: 5 penas de muerte; 77 reclusiones ( 26 durante el Gabinete MAURA y 51 durante los liberales posteriores); prisiones, 52 ( 3 con MAURA y 49 con MORET); arrestos, 85 (48 y 37, respectivamente); multas, 98 (73 y 25), absoluciones y sobreseimientos 1.053 (336 y 717). Como los sucesos del 27 se realizaron declarado ya el estado de sitio por el capitán general de la región $D$. Luis DE SANTIAGO (habiendo resignado el mando el gobernador civil D. Angel OSSORIO), a la Jurisdicción Militar correspondió enjuiciar las responsabilidades.

Fueron cerradas unas 100 escuelas laicas, entre las que se encontraban las fundadas por FERRER GUARDIA, por estimarse que propagaban enseñanzas nocivas para la infancia. Al caer MAURA y ser sustituido por MORET, el nuevo gobernador civil de Barcelona, CRESPOAZORIN, declaró que de las 100 escuelas cerradas, 80 funcionaban sin autorización. Ninguna fue abierta hasta los primeros días de febrero de 1910. $Y$ las fundadas por FERRER fueron expresamente condenadas ipor MORET!, quien no solamente llevó las disposiciones a La Gaceta (5

(3) "El Mercantil Valenciano», martes 3 de Agosto de 1909.

(4) "Los sucesos de España en 1909».

(5) Vid. CIERVA, Juan de la. "Notas de mi vida»; FERNANDEZ ALMAGRO, SEVILLA ANDRES. 
de febrero de 1910), sino que recalcó en sus declaraciones que se consideraban fuera de la ley, al igual que en Francia las creadas por HERVÉ, «por atentar contra el dogma, las instituciones y la moral social» (6).

El Mercantil Valenciano (lunes 23 de agosto de 1909) daba la noticia del cierre de las escuelas laicas y reproducía una crónica, enviada desde Madrid por Claudio FOLLO, con el título "Las escuelas neutras», donde se vertían conceptos como los que siguen:

"Soy un partidario decidido de la neutralidad de la enseñanza. Se cuida de que los niños, mientras que lo son, tengan desocupado de ingestiones nocivas el estómago y nadie se preocupa de que conserven la cabeza libre de dañinos perjuicios. Creo en la bondad y en la justicia de la educación neutral y laica...

Acaban de cerrar por orden gubernamental en Barcelona, unas escuelas neutrales, que no eran neutrales, que eran incubadoras de disolventes revolucionarios. Como me parece delictivo que se eduque al niño en la creencia de que se debe restablecer la Inquisición, me parece delictivo enseñar al niño que debe destruirse con dinamita todo el orden social».

Que existía un enorme forcejeo entre izquierdas y derechas en lo relativo a la enseñanza, se deduce de un trabajo aparecido en Las Provincias, de Valencia (18 de octubre de 1909), firmado por Juan de BACON. El autor relata la entrevista que sostuvo en París con Monsieur LAFERRE, Presidente de la Orden del Gran Oriente de Francia y diputado de los grupos más radicales del socialismo alli imperante (7).

CAMBÓ, en una carta a LA CIERVA, se quejaba de lo indiscriminatoria, y por ende, en algunos casos negativa, que habia resultado la medida:

«...Por el desconocimiento absoluto que tiene el señor Crespo-Azorín de Barcelona, han sido cerradas no sólo las escuelas en que se daban enseñanzas disoventes, sino... gran número de centros de cultura sana y moral, que la iniciativa privada había creado para elevar el nivel intelectual y moral de las clases obreras» (8).

(6) El Liberal, Madrid, 5 de Febrero de 1910.

(7) «No podemos prescindir de lo que suceda en estos momentos en Barcelona, debiendo defender a nuestros hermanos de España... Hay asuntos de verdadera trascendencia en los cuales todos nos hallamos animados de los mismos propósitos. Uno de esos asuntos, por ejemplo, es el que se relaciona con la enseñanza laica». Unos años antes, hacia 1905, la Tercera República Francesa, a instancias de los socialistas, promulgó leyes laicas relativas a la enseñanza. La separación de Iglesia y Estado, la secularización de éste. era tónica de la época, predominante a nivel europeo.

(8) PABON, Jesús. "Cambó...», t. l, pág. 341. 
Temía el líder de la Liga que ocurriese lo mismo con el avisado confinamiento de anarquistas;

«...Y veremos expulsadas y confinadas personas honorabilísimas... Si no se hermana la prudencia con la energía, dentro de algunas semanas la opinión habrá olvidado los sucesos de julio para recordar tan sólo las equivocaciones de la autoridad».

Fueron desterrados de España 40 ciudadanos extranjeros, ladrones, chulos de prostitutas, anarquistas de acción, vagos, indocumentados y maleantes. De Barcelona, en concreto, salieron 67 delincuentes comunes, carteristas, descuideros, indocumentados y 68 anarquistas de acción perfectamente identificados por sus antecedentes policiales. Casi todos ellos encontraron asilo político en Francia. Las autoridades gubernativas quisieron hacer ver, $y$ así fue de hecho en muchos casos mas que no en su totalidad, que se trataba de la escoria social.

Mucha tinta ha corrido sobre el carácter cruento de la represión. Hagamos un repaso de exégeta. José BRISSA - que señala la presencia de Ferrer Guardia al frente de los revoltosos y de los elementos directores cuando los sucesos de julio - nos dice que el contingente de tropas pała restablecer el orden, a disposición de las autoridades barcelonesas, era insuficiente para una ciudad de 8 kilómetros de ancha por uno de larga, y lo cifraba en unos 2.600 hombres entre soldados, Guardia de Seguridad y Guardia Civil. Esas cifras, según él, eran aproximadamente las oficiales, más elevadas que las reales por la necesidad de contar con las ausencias, permisos, bajas, etc. En realidad se disponía de 1.440 hombres. No sólo no tenía la autoridad, el lunes 26 de julio, ni siquiera elementos para un simulacro de represión, sino que estaba obligada a actuar con pies de plomo por la habilidad táctica con que procedían los dirigentes, presentando el motín como acto de protesta contra el envío de soldados a Africa, haciendo que los insurrectos vitorearan al Ejército y se produjeran corrientes de confraternización con la tropa (9).

BENET, por su parte, refiere:

«Por otro lado, los soldados eran vitoreados por los huelguistas que gritaban: «iAbajo la guerra!» En algunos momentos estuvo a punto de establecerse, entre la tropa y los huelguistas, una auténtica confraternización; la oficialidad empezó a temer por la disciplina de la tropa» (10).

SOL Y ORTEGA, en la entrevista concedida a El País (4 de agosto de 1909) aseveraba:

«El ejército fue incesantemente vitoreado, y estos vítores inspiraron

(9) “La revolución de Julio en Barcelona».

(10) «Maragall» y la Semana Trágica». «Edicions 62». Barcelona, 1965. 
uno de los bandos del general Santiago, anunciando que se haría fuego también sobre los que aplaudieran a las tropas").

OSSORIO Y GALLARDO, en carta al poeta Joan MARAGALL, se muestra partidario de la imposición de severos castigos por lo acontecido:

«Dirá que tengo un criterio medieval. Pero entre el honor de Barcelona y la vida de unos cuantos amigos de Sol y Ortega, prefiero el sacrificio de éstos al peligro de aquél» (11).

No perdamos de vista - ante estas terribles palabras - que OSSORIO dimitió de su cargo de gobernador civil, antes de resignar el mando en el capitán general D. Luis de SANTIAGO, por no estar de acuerdo con LA CIERVA, estimando improcedente la declaración del estado de sitio.

FERRER fue fusilado el 13 de octubre. Mucho antes de ese hecho - ya a fines de julio y principio de agosto - había comenzado la campaña de toda la extrema izquierda europea glorificando el movimiento sedicioso, propalando cifras exageradas acerca de las ejecuciones - cuando aún no se había producido ninguna - y asegurando la práctica en Montjuich de horribles torturas a los detenidos. El Daily Express publicó un telegrama de 4 de agosto conteniendo que esa fecha se había fusilado a treinta detenidos, y que ya iban pasados por las armas hasta ciento cincuenta. A partir de entonces se sucedieron infundios como este en: L'Humanité, L'Action, Le Peuple, La Guerra sociale, Beriler Tabeglatt... Un diario tan poco proclive a MAURA y los conservadores como El País tuvo que aclarar:

«En el documento del Comité (pro Ferrer) formado en París se han cometido dos grandes injusticias, que por amor a la verdad y aunque el Gobierno no lo merece, pero sí España, vamos a desvanecer. Creen que los Consejos de Guerra funcionan ilegal y cruelmente, y creen resucitados los tormentos de Montjuich. Ambas suposiciones son falsas, completamente falsas».

Pablo IGLESIAS hizo alarde de objetividad en la carta dirigida a CLERBAUT (17 de agosto de 1909, publicada en Le Peuple, de Bruselas el 22):

«El gobierno ha cometido muchas iniquidades y actos arbitrarios, pero no ha llegado a los extremos que le imputa la prensa de otros países».

Dentro del territorio peninsular hemos de destacar la oleada demagógica y pro-Ferrer desatada por Rodrigo SORIANO, desde La Nueva España y en Valencia desde El Radical. Torcuato LUCA DE TENA, pro-

(11) 20 de Octubre de 1909, publicada por José BENET en el libro arriba citado. 
pietario y director de $A B C$, se dirigió a varios periódicos del exterior reivindicando el buen nombre de España y de su gobierno (12).

En las Cortes de 1910, el diputado carlista DIAZ AGUADO manifestó que hubo prensa muy solvente en Europa que apoyó a España (hoy sabemos por los estudios de Victoria de DIEGO y Carlos SECO SERRANO que fue la alemana). Las Provincias, diario conservador de Valencia, el lunes 18 de octubre de 1909, se queja de la oleada de dicterios en la prẹnsa y de las manifestaciones contra nuestras Embajadas.

En España no se pidió el indulto del Director de la Escuela Moderna. De ahí la frase lapidaria de CAMBO: "Si culpa hay del fusilamiento de Ferrer, culpa es de todo el cuerpo social, principalmente de Barcelona; todos los ciudadanos de Barcelona hemos fusilado a Ferrer no pidiendo su indulto» (13). El jefe político de la Liga y otros cuantos regionalistas sí que solicitaron, en cambio, el del joven Clemente GARCIA (igualmente ejecutado), medio subnormal y empleado en una carbonería, que estaba acusado de la profanación del cadáver de una monja y de haber realizado un baile macabro con el mismo. Hubo quienes se retrajeron, también en este caso, pensando que constituía un precedente que obligaba a la solicitud en idéntico sentido con relación a FERRER. Empero, sí que abundaron los testimonios de condolencia por la campaña de difamación. "Hemos sido víctimas de una intervención moral del detritus de otras naciones", escribió OSSORIO a USERA (carta de 26 de octubre de 1909). En el mismo sentido se expresó Miguel de los Santos OLIVER en su artículo "Sobre el patriotismo» (14). Y CAMBO, en 1911, recordaba como, a nivel personal, la campaña de difamación le hizo sentir mayor amor hacia «todas las regiones de España unidas ante un solo insulto» (15). Pensaba que todo, desde la campaña pacifista a propósito de la intervención armada española en Marruecos hasta la crisis gubernamental de 1909, se debía a un claro interés internacional (16).

La trayectoria ideológica iniciada por el Daily Express ha seguido hasta nuestros días, y justo es que así sea - y será - mientras se den la bifurcación política e historiográfica consabida, a no ser que medie por encima de cualquier compromiso personal un ferviente deseo de imparcialidad. Gerald BRENAN, aunque carga $\because$-cesivamente de tintas

(12) SEVILLA ANDRES, Diego. "Antonio Maura. La revolución desde arriba». Ed. Aedos. Barcelona, 1953. Contiene íntegro el comunicado de " $A B C »$ en la pág. 355.

(13) PABON, J. "Cambó...», t. I, p. 340.

(14) " $A B C », 27$ de Noviembre de 1912.

(15) «El Regionalismo, factor de la Restauración de España». Conferencia en el Círculo de Zaragoza, 20 de Diciembre.

(16) «El moment polític», 4 de noviembre de 1909. PABON, J.t. I, p. 342. 
negras la actuación de CIERVA, no exime de responsabilidad a LERROUX y condena por igual el terrorismo rojo y blanco (chantajes de Juan RULL, confidente de la policía barcelonesa, a los sucesivos gobernadores Duque de Bivona, Manzano y Ossorio). (17).

BRUGUERA insiste igualmente en una dura acción represiva a cargo del ministro de la Gobernación (18). Salvador de MADARIAGA resaltó la sincronía de los momentos más álgidos del catalanismo con la acción de los agitadores terroristas, tal vez subvencionados por los políticos de Madrid (como acaeció con RULL; a su vez LERROUX era pagado a cargo del fondo de reptiles del ministerio de Gobernación) (19).

Coincide en el diagnóstico TUÑON DE LARA, que conceptúa a CIERVA y BUGALLAL (ambos partidarios de lanzar las tropas a la calle en abril de 1931) como abogados con importantes bufetes, de honda base caciquil en Murcia y Galicia, bien aupados en las esferas del Poder, defensores de pleitos de oligarcas como el de la Condesa DE BORNOS a cargo del primero, constituyendo ambos «dos puntales del conservadurismo» (20). Elena de LA SOUCHĖRE trazó un cuadro de la represión muy sombrio, cargando más contra MAURA que contra CIERVA (21).

Pero es Constancia de la MORA Y MAURA (nieta de D. Antonio y casada civilmente en segundas nupcias con el general Hidalgo de Cisne-

(17) «El laberinto español», Ed. Ruedo Ibérico, Paris, 1964. p. 27 y nota 2 en la p. 37.

- Sobre el controvertido proceso de Juan RULL puede consultarse "Las Provincias», diario conservador de Valencia. Día 28 de Marzo de 1908; 31 del mismo, "Lo que dice Bivona»; $1^{\circ}$ de Abril; 3 de Abril; 4 del mismo; domingo, 5; el lunes, 6 de Abril la reproducción de los debates parlamentarios sobre terrorismo y anarquismo; el martes, 7 nueva información sobre la ley de excepción contra los anarquistas y terroristas; el miércoles, 8 , las declaraciones de Enrique PRAT DE LA RIBA, Presidente de la Diputación de Barcelona, como testigo del proceso contra RULL; 9 de Abril de 1908, «Desde Barcelona. Impresiones»; en la misma fecha, comentarios sobre la ley de represión del terrorismo con el epígrafe "Asuntos del día»; el viernes, 3 de Abril de 1908, ubicación del terrorismo de Barcelona en un contexto internacional y el comentario "La prensa francesa y el terrorismo". Según éste, un redactor de Le Matin: «celebró una interviú con LERROUX que manifestó que era ajeno por completo a todo lo relacionado con el terrorismo y que si Rull habia lanzado calumnias contra él era a causa del despecho». La prensa francesa seguia con enorme interés las sesiones del proceso RULL. Por otro lado, el Presidente de E.E.U.U., ROOSEVELT, tuvo que solicitar del Senado medidas extraordinarias contra los anarquistas en especial contra el matonismo de Chicago y New York. Se trataba de un fenómeno a escala mundial. Además de sus connotaciones políticas, estaba ligado a la carestía económica y al paro. (A la fluctuación cíclica contractiva de 1907; crisis de superproducción en U.S.A.).

(18) «Historia contemporánea de España».

(19) «España...».

(20) «Estudios...», pp. 232 y 236.

(21) «Explication de l'Espagne». Vid. PEREZ Y GOMEZ, A. cap. titulado «La ferrerada». 
ros, jefe de la aviación republicana en 1937) quien más especialmente se ensaña contra el político balear:

«El primer levantamento popular, durante el reinado de Alfonso XIII, tuvo lugar en 1909 cuando mi abuelo manchó su historia de patriota y líder conservador, firmando junto con el rey, la sentencia de muerte de Francisco Ferrer... Ferrer fue la víctima propiciatoria de un gobierno débil y asustado por los acontecimientos de la «Semana Trágica» que tuvo lugar en Barcelona... Pero incluso en Barcelona las revueltas traían consigo menos derramamiento de sangre que las represiones que las seguían» (22).

Resulta tendenciosa la versión de Gerald BRENAN, al suponer que Ferrer no estaba en Barcelona - sin verificar la hipótesis - y que se le condenó prejuzgando el tribunal militar su papel como inductor en el atentado de la Calle Mayor (con motivo de la boda regia de Alfonso XIII y Victoria Eugenia) (23).

El cliché que nos ha quedado como válido de CIERVA en Gobernación (debido a estos lamentables sucesos) no es el del tímido legislador social (pionero en su gestión), con iniciativas cuya paternidad después se atribuiría a DATO, que las llevó a la práctica. No es el del trabajador infatigable y excelente orador parlamentario que divulgó «AZORIN». Ni el del asiduo colaborador de D. Gumersindo de AZCARATE, Director del Instituto de Reformas Sociales. CIERVA en Gobernación, en 1907-9, es nada más y nada menos que el represor de Barcelona.

"La Cierva - escribió Juan APARICIO - era un murciano de choque, como los murcianos del Sindicato Unico, cuando el tono de la existencia española era desgarrado y superficial, aguantando periódicamente las inundaciones, las huelgas, las epidemias y los comicios... Aparecía un despistante contraste, que mientras en Barcelona los murcianos cenetistas eran los fautores del desorden, otro murciano era la encarnación en Madrid de la autoridad con pantalones de cuadro" (24).

Baltasar PORCEL entiende así el binomio MAURA-CIERVA:

"(Maura) Al parecer siempre poseyó un "prestigio moral» que le daban, supongo, su porte, su fraseología, ya que no su sempiterno ministro de la Gobernación, el señor La Cierva, de aficiones desmedidas a

(22) «Doble esplendor». México, 1944.

(23) «El laberinto...», p. 37.

(24) «Encomio del murciano». En el diario Pueb/o, de Madrid, 17 de Mayo de 1958. Los caricaturistas pintaban a CIERVA con pantalones cuadriculados o con «la manta liada a la cabeza». Aquella prenda de vestir llegó a serle tan característica como a SAGASTA, ministro de Gobernación en 1868-9, su tupé o actualmente a FRAGA IRIBARNE - de muchas concomitancias con el primero- sus tirantes. 
la contorsión del prójimo, al garrote más eficaz y en favor suyo (...). Ya sabemos que Maura manejaba el lapidario discurso y La Cierva las fuerzas del orden y el desorden» (25).

G. de AZCARATE (encarnación de la "otra España", la de la Institución Libre de Enseñanza) con inteligente ironía manifestó:

«S.S. es en la paz un buen ministro, competente, laborioso, recto; pero en la guerra, ¡Dios nos libre que vuelva a ser ministro!... S. S. sería un gran ministro, si se quitara del Ministerio de la Gobernación la Sección de Orden Público»i (26).

El Director del Instituto de Reformas Sociales, en este mismo discurso parlamentario hizo justicia a la eficiencia de CIERVA como diligente legislador social.

\section{b) ALGUNAS APORTACIONES LEGISLATIVAS DEL MINISTRO DE GOBERNACION, JUAN DE LA CIERVA, EN EL AMBITO LABORAL}

En el presente apartado trataremos de analizar que el ministro que tu-

(25) Destino, 2 de Noviembre de 1965, artículo «Maura y sus mauristas». El subrayado es nuestro.

(26) D.S.C. Congreso, sesión de 8 de Abril de 1911. El subrayado es nuestro.

- Jesús PABON trazó ester perfil psicólogo de CIERVA: «iCurioso tipo el de D. Juan! Constituyó en la política española de su tiempo un fenómeno interesante, merecedor de un serio estudio. Impasible entre los odios y los entusiasmos que despertó, cacique "canovista" y figura importante en la corriente renovadora de Maura, ajeno a complicaciones doctrinales y decidido hombre de acción, autoritario que sabia manejar la fuerza física sin entender el problema de la metafísica de la fuerza, parecia encarnar el orden en su más simple acepción, susceptible al ser aplicabo de innumerables contradicciones. Incurria ahora en una serie de ellas».

A propósito de su acceso a la Cartera de Guerra, después de la crisis de 1917, apoyado en el Gabinete presidido por GARCIA PRIETO por las Juntas Militares de Defensa, sigue afirmando PABON;

«Hombre de gobierno, hacía imposible la vida de aquél en que formaba; político autoritario, representaba la subversión militar en el Poder; partidario de las Juntas, se enfrentará con el crecimiento y la desviación de la rebeldía sin percibir la lógica rigurosa de las consecuencias. Su simple concepción del orden y su actuación decidida sumieron a la vez, en el caos, la existencia del Gobierno y la vida pública española... Hizo imposible, decíamos, la vida del Gobierno. No entendia la opinión de Sánchez Toca quien juzgaba mostruoso que los instintos armados uasimilaran el derecho de sindicación de los inermes valiéndose de las armas que el poder público les confia» y fueran "suplantando todos los poderes y aboliendo la soberanía del Estado» (PABON, J. «Cambó....», t. I, p. 599, cap. «El general y el asistentem).

- Se le llamó "dictador al dictado" y él en sus «Notas de mi vida» niega que quisiera serlo; al parecer recibió incitaciones de Alfonso XIII en este sentido en un viaje realizado por ambos a Córdoba (FERNANDEZ ALMAGRO. «Historia política del reinado...). En La Correspondencia Militar pudo leerse: «Sépase que desde la época del general Cassola, jamás hubo, hasta hoy, ministro alguno que contara con más simpatías en el estamento militar». 
vo que hacer frente a los sangrientos sucesos de la Semana Trágica, como representante del país oficial, intentó, al menos sobre el papel, una serie de medidas destinadas a: proteger a la infancia, los emigrantes, mejor dotación de los servicios de Beneficencia y Salud Pública, y, sobre todo la creación del Instituto Nacional de Previsión (I.N.P.). Esta gestión social se inserta de lleno en lo que algunos llaman «la corriente renovadora de Maura» y otros "la revolución desde arriba».

Protección a la infancia. - El Decreto de 10 de mayo de 1907 se promulga para dar eficacia a los artículos 156 y 157 del Código Civil, por él se crea una escuela de reforma y asilo paternal de jóvenes y se destina un millón de pesetas a la construcción del reformatorio madrileño de Vista Alegre. La Real Orden de 30 de octubre de 1908 es referente al exacto cumplimiento de la ley de 12 de agosto de 1904 de protección a la infancia, especialmente sobre el trabajo peligroso de los niños, vagancia y mendicidad de los menores de dieciséis años.

El vacío que suponía una ley importante como la de Agosto de 1904 sin un reglamento de aplicación durante varios años, fue salvado por CIERVA mediante el reglamento del 24 de enero de 1908, que se compone de 57 artículos y que aborda las disposiciones de la ley a través de los siguientes contenidos: acción protectora de la infancia, consejo superior, juntas provinciales, juntas municipales, secciones de ambas, auxiliares de la función, premios y recompensas y organización económica del Consejo. La protección a la infancia comienza con el amparo a la mujer embarazada, en la reglamentación de la lactancia mercenaria, inspección de casas-cunas, escuelas, talleres, espectáculos y de cuantos centros alberguen o recojan a niños; en la investigación de todos los daños que se puedan inferir a los menores; la denuncia y persecución de los delitos contra ellos cometidos; el amparo a los niños abandonados; la corrección paternal de los llamados incorregibles, educación e instrucción de los anormales y estudio constante de las reformas de una Liga internacional de protección a la Infancia. Esta acción protectora se ejerce a través del Consejo Superior, que depende del Ministerio de Gobernación y preside el Ministro, juntas provinciales y locales. El amparo específico es sobre los menores de 16 años y al contingente de todos los menores de edad alcanzan las atribuciones generales. Este reglamento constituye una disposición legislativa sumamente sugestiva, ya que en vez de sanciones y punición de hechos establece premios y recompensas, que pueden alcanzar a nodrizas, maestros, médicos, directores de fábricas y talleres, fundadores de instituciones y donantes en favor de la infancia. En 1979, en que se celebró el "Año Internacional del Niño» cobró actualidad esta normativa española coincidiendo con el septuagenario de su promulgación. 
La aplicación del Reglamento aún se desmenuza en un Real Decreto de 24 de enero de 1908, relativo a las atribuciones que competen al Consejo Superior y a las juntas provinciales y locales de protección a la infancia, en cuanto se refiere a la mendicidad; en una orden-circular a los gobernadores provinciales sobre el modo de constitución de las juntas provinciales, de 28 de febrero del mismo año, y en un Decreto de 21 de marzo de 1909, relativo al Consejo Superior de Protección a la Infancia (27).

\section{Ley de Emigración}

«Maura me encargó que preparase una ley reglamentando la emigración. Quería evitar los abusos que cometían intermediarios, agentes y compañías navieras. Cuando terminé las elecciones elaboré el proyecto ayudado por Puyol, secretario del Instituto de Reformas Sociales y me parece que por Sangro, exministro de Trabajo en el Gabinete Berenguer; fue una de nuestras más importantes reformas, que todavía en lo esencial perdura. La protección al emigrante al ausentarse, en el barco, a su llegada, durante su estancia en país extranjero y a su vuelta; tales fueron los principios que inspiraron la ley» (28).

Así se refiere el propio CIERVA a la ley de 21 de diciembre de 1907. Sus epígrafes, desarrollados en seis capitulos y sesenta y un artículos, son: de la emigración y los emigrantes, régimen de emigración, navieros o armadores y de los consignatarios, del contrato de transporte de los emigrantes, inspección y sanciones penales. Todo lo referente a la emigración dependerá del Ministerio de la Gobernación, en donde se crea un Consejo Superior y un Negociado de Emigración; a los cónsules españoles se atribuye un control general de todos los emigrantes; se crea una inspección para el cumplimiento de todos los extremos contenidos en la ley y una punición para sus infractores, etc... A esta ley la completó un extenso Reglamento, 185 artículos, de 30 de abril de 1908, en que se desarrolla bajo idénticos epígrafes las normas generales de aquélla.

Sanidad y Beneficencia. - No es despreciable (dado el retraso español en ambos aspectos) la gestión de CIERVA en estas cuestiones. Entresaquemos algunas disposiciones.

1) En Sanidad: creación en Madrid de un patronato central de dispensarios e instituciones antituberculosas, bajo la presidencia de la Reina Victoria Eugenia (Decreto de 27 de diciembre de 1907); reglamentación

(27) Vid. SERRA RUIZ, Rafael. "Juan de la Cierva, jurista murciano» Patronato de Cultura de la Excma. Diputación Provincial de Murcia, 1962. 96.

(28) CIERVA Y PEÑAFIEL, Juan de la. «Notas de mi vida». Instituto Ed. Reus, 1955, p. 
legal de los dispensarios e instituciones contra la tuberculosis (órdenes de 6 de julio de 1908 y 18 de enero de 1909) y de la comisión permanente para combatir esta enfermedad, así como normas sobre la reorganización de la junta central y provinciales de la comisión permanente de la misma materia (Orden de 13 de febrero de 1908); una Real Orden de 4 de enero de 1908, relativa a la construcción de un edificio para el Instituto de Sueroterapia, vacunación, bacteriología; campaña sanitaria contra el cólera procedente de Rusia (R.R.O.O. de 25 de septiembre y 17 de óctubre de 1908); construcción del edificio destinado a Instituto Nacional de Higiene, del que fue director RAMON Y CAJAL (D. de 2 de abril de 1908); aprobación del Reglamento de Sanidad Exterior (D. 14 de enero de 1909); reglas sobre los inspectores provinciales de sanidad (D. 12 de enero de 1909); creación de cuatro unidades sanitarias o brigadas volantes (O. de 8 de febrero de 1909); normas sobre vacunación obligatoria, intrusismo en medicina, estadística demográfica, creación de estaciones sanitarias y lazaretos, lucha contra el tifus exantemático.

2) En Beneficencia:

«La beneficencia particular estaba completamente abandonada - escribió CIERVA en sus Memorias - . En un desván de Gobernación se acumulaba el archivo de la Beneficencia particular de España, durante los años de la revolución y la República (se refiere al sexenio 18681874) o tal vez desde antes de esos tiempos. El cúmulo desordenado de escrituras de fundación, cuentas y documentos de todas clases siguió en informe montón, con el grave riesgo comprobado, de desaparecer muchos de tales documentos, por incuria o por sórdido interés de patronos y administradores, que habían devorado o dejado devorar bienes por valor de muchos millones. A esa incuria, en relación con el archivo, correspondía la de las juntas provinciales en el cumplimiento de sus deberes de inspección e intervención con arreglo a las leyes» (29).

A tan caótica situación se apresuró CIERVA a poner correctivo legal. Por R.O. de 24 de marzo de 1908 se dispuso la formación y publicación en la Gaceta de Madrid de la estadística general en la beneficencia de España. La circular de 10 de enero había ya recomendado el funcionamiento normal y activo de las juntas de beneficencia. En 27 de octubre se promulga una R.O. para proceder al cabal reconocimiento de todas las fundaciones benéficas. En 18 de febrero de 1909 se decreta una circular conteniendo prevenciones relativas a los bienes de las fundaciones benéficas de carácter particular y en 14 de mayo se dispone que los administradores de las fundaciones han de presentar justificantes del

(29) Ibidem, p. 111. 
cumplimiento de cargas. Citemos, por último, sendas circulares para garantizar el cumplimiento de los fines de beneficencia y sobre inversión de bienes y valores de las fundaciones encaminadas a este objetivo.

Cierto que, pese a las buenas disposiciones personales y al furor legislativo de CIERVA, la situación de los estratos menesterosos de la población española permaneció invariable. Más que medidas en favor de la Beneficencia hacian falta drásticas reformas en aras de la Justicia (empezando por una Ley Modificadora Agraria, adecuada, en Andalucía y Galicia muy especialmente).

Creación del Instituto Nacional de Previsión. - Tal vez la aportación jurídica más trascendental de CIERVA en Gobernación sea la relativa al Derecho del Trabajo. Ya hemos alertado al lector sobre el disculpable tópico de personalizar en CANALEJAS y sobre todo en D. Eduardo DATO casi todas las disposiciones laborales anteriores a 1925. DATO dictó importantes leyes (accidentes de la industria, trabajo de mujeres y niños, proyecto sobre el descanso dominical, etc...) y a su iniciativa se debe la creación del Ministerio de Trabajo, pero es preciso reivindicar en favor de CIERVA una acción laboral acertada y perdurable. Es esta una de las paradojas del célebre ministro de la Gobernación, bien destacadas por PABON y el periodista Juan APARICIO: CIERVA represor de los murcianos de choque, cenetistas, emigrados a Barcelona, cuando los sucesos de julio de 1909... y CIERVA precursor de la legislación social española. (También fue BISMARCK un adelantado en este sentido, después de 1870, a pesar de no ser demócrata ni por convicción ni por ' temperamento).

La gestión laboral de CIERVA se resume numéricamente en treinta y tantas reales órdenes, una docena de decretos, cuatro o cinco leyes y varias circulares. Hay que tener en cuenta que en el cuasi trienio 19071909 , en que el político murciano fue titular de la cartera de Gobernación, no existía aún el Ministerio de Trabajo, nacido en 1920, y la cuestión laboral iba implícita a la Cartera mencionada. Por entonces ya tenían un "rodaje» y un acrisolado prestigio las "Trade Unions» inglesas. $Y$ desde 1864, con Napoleón III, estaba abolida en Francia la Ley Chapelier (1791) que prohibía la formación de asociaciones de obreros y de patronos. El problema laboral en España, tan complejo y acuciante, estaba en período de iniciación. La corta vida de esta rama jurídica en nuestro país, la clasifica HERNAIZ, hasta la década de 1960, en cinco períodos, y los años 1907-1909 pertenecen a los albores de la segunda fase. Entre las disposiciones promovidas por CIERVA destacan la ley y reales decretos relativos a la creación del Instituto Nacional de Previsión; leyes referentes a conciliación, arbitraje y tribunales industriales; ley de coaligaciones, huelgas y paros... Y, a pesar de ello, es difícil en- 
contrar un Tratado de Derecho del Trabajo Español en que se haga la más mínima alusión a esta empresa político-administrativa-jurídica de CIERVA.

La Ley creadora del Instituto Nacional de Previsión es de 27 de febrero de 1908. Consta de cuatro capítulos (fines y organización; operaciones del Instituto; derecho especial y relación con otros Institutos de análogos propósitos) con cuarenta artículos y tres disposiciones transitorias. Su finalidad primordial consistió en prever el retiro obrero, y asi sé habla en el art. $1^{\circ}$ de la Ley. El Real Decreto de 24 de diciembre de 1908 ordena que el Instituto quede constituido antes del día $1^{\circ}$ del mes de enero siguiente y aprueba sus estatutos provisionales, ratificados definitivamente por una R.O. del 26 del mismo mes. Finalmente, el Decreto de 10 de diciembre de 1908 fija los numerosos y estrictos requisitos que han de reunir las entidades que pretenden asimilarse al Instituto $\mathrm{Na}$ cional de Previsión.

Ley de huelgas, coaligaciones y paro.

«Se aprobaron la ley de huelgas, la de arbitraje y conciliación y la de aprendizaje. En la primera se previó, condicionándola, la huelga ferroviaria. Resultó una de las más avanzadas leyes sociales del mundo. Si se hubiera aplicado siempre con lealtad y la masa obrera no hubiera sido envenenada por los agitadores y ambiciosos políticos, habría sido un cauce legal de provechosos frutos dentro de la lucha de clases. Desgraciadamente, lo que se ha practicado y lo que se practica - nos dejó escrito CIERVA - es el desconocimiento o la indiferencia ante la huelga revolucionaria, que en el Código Penal de la Dictadura se castiga, y ahora en la ley de defensa de la República se dice también que se castiga, pero aquel Código lo han derogado y todavía no hemos visto verdadero castigo por las innumerables huelgas revolucionarias que en estos momentos se han producido» (30).

La huelga fue reglamentada por CIERVA, en un epígrafe conjunto a coaligaciones y paros, por ley de 27 de abril de 1909. Es esta una ley un tanto contradictoria en sí misma. Se admite la huelga como lícita, pero se la reglamenta severamente. (No perdamos de vista el significado que atribuye Anselmo LORENZO a la huelga de 1902 en Barcelona). La misma fórmula de promulgación, aunque usual, parece enunciada con tono de bando de guerra - subyaciendo en ella esa "energía» personal de CIERVA, que le reconocía como un mérito su enemigo político ROMANONES y que tanto agradaba al estamento castrense, en las ocasiones

(30) Ibiden, p. 120. Canalejas tendrá que hacer frente a la huelga general ferroviaria, pocos años después. 
en que fue ministro de Guerra - : «Don Alfonso XIII, por la gracia de Dios y de la Constitución, Rey de España. A todos los españoles que la presente vieren y entendieren, sabed: que las Cortes han decretado y Nos sancionado lo siguiente...) (No perdamos de vista que, recién nombrado ministro de la Gobernación, CIERVA declaró el estado de sitio en Valencia - excediéndose - por haberse producido una huelga de los vendedores de los mercados contra el arrendatario de los arbitrios).

La ley resulta mixtificada, ecléctica, indecisa y contradictoria, tolerante y restrictiva a la vez: "Tanto los patronos como los obreros pueden coaligarse, declarase en huelga y acordar el paro para los efectos de sus respecivos intereses... las huelgas y paros serán anunciados a la autoridad con cinco u ocho días de anticipación, según casos..., las asociaciones legalmente constituidas podrán formar o sostener coaligaciones, huelgas o paros con arreglo a lo dispuesto en la presente ley».

En tan sólo once artículos se habla, no obstante, con reiteración machacona de casos de punición, violencias, amenazas, transgresiones, procedimiento penal... No hay que ser un FREUD para comprender que el legislador no cree en la operatividad dentro del orden de la medida que regula, a la que debe creer, más bien, generadora de perturbaciones y tribulaciones sin cuento para el gobernante.

Para nosotros "los iberos" (como diría ORTEGA Y GASSET), la palabra huelga, pese a que se puede hablar del arte hispánico del "holgar» es enigmática y difícil. Buena prueba de ello es la definición que del vocablo hace Rafael SERRA RUIZ: «hecho colectivo que generalmente viene a ser una exteriorización injusta y multitudinaria de razones individuales justas». La tradición huelguística española resulta breve y casi trágica, sin la solera de la inglesa, que se remonta a 1824, ni de la francesa, a cuarenta años más tarde. No existía otro precedente en España para CIERVA que el art. 556 del Código Penal de 1870, que, por cierto, quedaba derogado.

El propósito «teórico» de CIERVA, de dar reconocimiento jurídico o legal en nuestro pais a la huelga, resulta laudable y supone el inicio de un recorrido. En la «praxis» ya sabemos como nuestro personaje resolvia las huelgas: repetimos que declarando el estado de guerra en Valencia por la huelga de las verduleras de Monteolivete que protestaban contra el Sr. Salmón, arrendatario de los arbitrios; procesando y encarcelando en Valencia al Catedrático de la Facultad de Medicina, Dr. MOLINER y a su hijo, como inductores de los alborotos promovidos por los estudiantes de $5^{\circ}$ curso; en 1909, en Madrid, clausurando la Casa del Pueblo y sometiendo a control - fue detenido- a Pablo IGLESIAS; militarizando los Cuerpos de Correos y Telégrafos, cuando hacían recurso a ella los empleados de Comunicaciones... y un largo etcétera. 
Tribunales industriales. - La ley de 19 de mayo de 1908 sobre Consejos de Conciliación y Arbitraje Industrial había regulado el modo de evitar las huelgas mediante la intervención de los organismos que creaba. Cuando se prepare o se haya producido una huelga, los obreros deberán comunicarlo, dentro de las veinticuatro horas, al presidente de la Junta Local de Reformas Sociales e igual obligación se impone a los patronos que pretenden el paro (lock-out, cierre empresarial) con una semana de antelación, debiendo exponer ambos por escrito las causas de la huelga o paro con todas sus circunstancias. De tales escritos se da traslado a la otra parte para que exprese si acepta una posible mediación $y$, aceptada, se nombra Consejo de Conciliación, compuesto de seis jurados, tres de ellos de la lista elegida por los patronos y tres de la elegida por los obreros. El Consejo oirá a las partes y recabará de ellas que los patronos no suspendan el trabajo ni los obreros lo abandonen mientras se tramita la conciliación. Si no se obtuviera avenencia, se acude al arbitraje mediante convenio de compromiso y nombramiento de uno o más árbitros, etc.

En el mismo día 19 de mayo de 1908 dictóse la ley relativa a Tribunales industriales. El Gobierno podía decretar el establecimiento de estos órganos en cabezas de partido judicial cuando lo estimara oportuno y lo solicitaran obreros y patronos del territorio, previo informe de las juntas locales y provinciales, cámaras agrícolas y de comercio; el Tribunal estará presidido por el juez de primera instancia y compuesto por tres jurados elegidos por el litigante obrero de entre las listas de patronos y otros tres jurados designados a la inversa. Conocerán de las reclamaciones civiles entre patronos y obreros sobre incumplimiento o rescisión de contratos de arrendamientos de servicios, contratos de trabajo o aprendizaje y de los pleitos que surjan entre la aplicación de la ley de accidentes de trabajo; el procedimiento es verbal y sumario, con conciliación previa. Contra la sentencia se dan recursos de apelación ante el mismo tribunal en pleno y de nulidad para la sala de lo civil de la Audiencia Territorial correspondiente... El Decreto de 20 de octubre de 1908 creó en toda España cerca de doscientos tribunales industriales.

La práctica demostró que los defectos de esta ley eran bastantes, $y$, sin embargo, no fue sustituida hasta 1922. La historia de la jurisdicción laboral en España se reduce, sustancialmente, a estos Tribunales Industriales, Jurados Mixtos y Magistraturas de Trabajo. De modo, pues, que aquellas disposiciones de CIERVA, aunque pacatas y alicortadas, nutren casi la tercera parte de esta reciente y balbuciente historia jurídica (con sustanciales cambios después de 1975). Todo ello nos dará idea del desamparo - jurídico y práctico - del trabajador español cuando estalló la convulsión de Barcelona de julio de 1909. 
Salario y otros extremos. - El Decreto de 18 de julio de 1907 pone remedio a la siguiente situación laboral:

"...Abusos que algunos patronos y con más frecuencia los destajistas, capataces y otros empleados vienen cometiendo, ya para obligar a los trabajadores, directa o indirectamente, a proveerse de géneros y alimentos en las tiendas por aquéllos establecidas, ya en el modo de hacer efectivo el salario, ya, en fin, lo que se refiere al abono del mismo en lugares de recreo o en tabernas, cantinas y tiendas en donde los obreros se surtan durante la semana...» (exposición de motivos).

Este decreto prohibe el establecimiento en fábricas, minas, obras y explotaciones, de tiendas, cantinas o expendedurías que pertenezcan a los patronos, destajistas, capataces, etc...; se autorizan economatos a condición de que las ventas se hagan por el precio de coste de los géneros...; el pago de salarios ha de hacerse con moneda de curso legal y no podrá realizarse en lugares de recreo, taberna, cantina o tienda.

Descanso dominical. - La Ley de descanso dominical es anterior 13 de marzo de 1904) a la gestión de CIERVA, pero son numerosísimas las disposiciones de éste para la ejecución de la ley, así como la promulgación de otras nuevas para el cumplimiento del descanso semanal. La Real Orden de 5 de febrero de 1909 recomienda al Instituto de Reformas Sociales la conveniencia de revisar el reglamento de la ley de descanso dominical y la proposición al Gobierno de todas aquellas reformas que crea procedentes. Las disposiciones legislativas de CIERVA sobre esta materia son muy abundantes (R.R.O.O. de 14 de agosto, 3 y 13 de septiembre, 18 de octubre, 19 y 27 de noviembre, 7 y 13 de diciembre de 1907; R.D. de 24 de enero, R.R.O.O. de 30 del mismo mes y de 7 de febrero; 5,9 y 15 de junio, 6 de agosto, 31 de octubre de 1908; 2 de enero, 21 junio, 31 de julio de 1909... etc). OSSORIO Y GALLARDO, como gobernador civil de Barcelona, se concitó muchas antipatías - sobre todo entre el "gremio» de los barberos y peluqueros - por exigir su estricto cumplimiento.

Trabajo de niños y mujeres. - La Orden de 2 de julio de 1907 se refiere a la clasificación de las industrias relacionadas con el trabajo de mujeres y niños. La de 12 de julio concierne a la ratificación en España del «Convenio de Berna» sobre el trabajo nocturno de mujeres, y dispone se confeccione un previo informe por el Instituto de Reformas Sociales. El Decreto de 25 de enero de 1908 clasifica las industrias y trabajos que se prohiben total o parcialmente a menores de 16 años y a mujeres menores de edad y la Orden de 19 de febrero esclarece extremos de aquel decreto. Por último, la orden-circular de 15 de julio de 1908 estimula a los gobernadores para que colaboren en la información enco- 
mendada al Instituto de Reformas Sociales acerca del trabajo de mujeres verificado por la noches.

Otras aportaciones laborales. - La gestión de LA CIERVA en el aspecto social, a pesar de todas sus inherentes contradicciones, es más extensa e importante de lo que se pudiera pensar "a priori», máxime viniendo de un personaje que ha gozado de «mala prensa», en parte por la campaña desatada contra él por el célebre «trust» periodístico de Miguel MOYA (El Liberal, El Heraldo, El Imparcial) con bastante anterioridad a la Semana Trágica. Impopularidad que ha llegado intacta hasta nuestros días.

La Inspección de Trabajo fue objeto de las R.R.O.O. de 15 de marzo y 22 de julio de 1907 y la del 28 de enero del año siguiente resuelve una amplia y difícil moción planteada desde Barcelona sobre la prevalencia de la ley relativa al trabajo de mujeres o niños o del Real Decreto referente a funcionamiento de disposiciones laborales. Una Real Orden de 26 de junio de 1907 dicta normas aclaratorias acerca de los pactos entre patronos y obreros y otra de 21 de junio de 1908 inicia la estadística nacional de estos pactos laborales.

En el ramo de accidentes de trabajo se dieron las órdenes de 23 de octubre de 1907 y 24 de enero de 1909 acerca de las empresas autorizadas para sustituir al patrono en las obligaciones derivadas de la ley de accidentes laborales. Orden de 14 de noviembre del mismo año relacionada con la estadística de dichos accidentes y la de 8 de enero de 1908 crea numerosas plazas en el Asilo de Inválidos del Trabajo. La Real Orden de 7 de mayo de 1909 dispone se manifieste la complacencia con que S.M. ha visto la adhesión de diversas Cajas de Pensiones para la vejez y ahorro y la colaboración prestada a los fines del Instituto Nacional de Previsión por varias Cajas de Ahorro y Montes de Piedad...

La gestión social de CIERVA, en el bienio 1907-1909 en que fue ministro de la Gobernación, acredita que no teorizó sobre el Derecho del Trabajo, pero sí dictó normas para esta cuestión jurídica, tan atrasada en nuestro país. Remedios que, dado su retraso cronológico y las agudas tensiones sociales existentes, no siempre lograron resultar eficaces. Con todo, como iniciador, y en condición de tal, debería ser incluido entre los juristas prácticos de la época moderna de dicha materia. Sus disposiciones adolecen de defectos, dada esa misma incipiencia. Los iniciadores de cualquier empresa presiden la etapa más difícil y comprometida. La teoria jurídica unas veces precede al hecho y otras lo concluye. Sabemos, por la rápida pero perspicaz semblanza psicológica de J. PABON, que CIERVA no era un temperamento dialéctico ni dado a las disquisiciones teóricas o metafísicas, sino eminentemente práctico; pero son imprescindibles estos hombres que no se detienen demasiado en 
el sistema mental y científico previo ni en la meditación sintética y anteriormente sistemática, sino que simplemente estudian la realidad del hecho social y el remedio jurídico en forma de ley (dentro de un marco de amplias limitaciones, en este casol.

El ordenancista intransigente, otro ALCUBILLA por su proliferación legislativa para Melchor FERNANDEZ ALMAGRO, concebidor del orden en su más rígida acepción que para muchos historiadores y periodistas fue CIERVA, quizás en su fuero interno no carecía de ética y sensibilidad hacia la justicia social, según nos quiso hacer ver "AZORIN». De todos modos el curso de los acontecimientos dispuso que prevaleciera la primera imagen sobre la segunda.

"Lo que va expuesto - escribió José MARTINEZ RUIZ-, permite colegir lo que el señor la Cierva hubiera realizado, de disponer de más tiempo, en favor de las clases obreras. Proyectos importantes quedaron detenidos en las Cámaras. Se presentó al Senado el proyecto de contrato de trabajo. Se sometían en este proyecto a los tribunales industriales la jornada máxima de trabajo y el jornal mínimo, con relación a la validez de los contratos. Aún a los mismos liberales, -uno, el señor Santamaría de Paredes - pareció demasiado radical la reforma. Quedó pendiente también el proyecto relativo al contrato de aprendizaje. A cuantos se preocupan del bienestar del obrero interesa la cuestión de las viviendas higiénicas y baratas. En el preámbulo del proyecto sobre el contrato anunció también el señor La Cierva la preparación de un proyecto sobre retiros y pensiones obreras para la vejez. Finalmente, redactado tenía el ministro, para presentarlo a las Cortes, otro proyecto, por el que se extiende a los obreros del campo la ley de Accidentes de Trabajon (31).

Reformas sociales. - El Instituto de Reformas Sociales se remonta a 1903 y su gestión está íntimamente relacionada con las leyes laborales de la época. Fue presidido eficazmente, durante muchos años, como venimos anticipando, por D. Gumersindo de AZCARATE. Durante la etapa de CIERVA en Gobernación dio pruebas de notable actividad, interviniendo en la promoción e informe de gran parte de las disposiciones relativas al Derecho del Trabajo, ya enumeradas. Entresaquemos alguna que otra cita legal. El Decreto de 4 de junio de 1907 creó en el Ministerio de la Gobernación una sección especial de reformas sociales, cuyo objetivo principal era servir de punto de enlace y de relación entre el Instituto y el Ministerio. El decreto de 18 de noviembre de 1908 es relativo al trabajo de niños en las industrias relacionadas con la nagevación. La Real

(31) «AZORIN» (José MARTINEZ RUIZ). "La obra de un ministro», pp. 47-48. 
Orden de 20 de junio de 1907 determina la forma en que han de funcionar las juntas de reformas sociales; la de 11 de marzo del mismo año dispone que Juzgados y Audiencias remitan al Instituto las sentencias ejecutivas sobre accidentes del trabajo; la del 13 de diciembre faculta a las juntas locales para inspeccionar el cumplimiento de la ley sobre el descanso dominical. Otra de 11 de enero del siguiente año encarga al Instituto el estudio del problema de la mendicidad y el 29 del mismo se promulga la que hace referencia a la organización de las juntas provinciales; la circular de 30 de abril de 1908 ordena a los gobernadores que remitan al Ministerio la relación de Asociaciones inscritas en el Instituto de Reformas Sociales y la Orden de 2 de julio de 1909 cursa instrucciones a las que sujetarse el servicio de estadísticas del trabajo en relación con las reformas sociales convenientes.

Reforma de la policía. - Se produjeron sustanciales modificaciones que son resumidas por el propio CIERVA en sus "Notas de mi vida»:

«...Se hizo la transformación total de la policía..., se estableció la oposición como forma de ingreso..., se creó la Escuela de Policía, las Jefaturas Superiores de Madrid y Barcelona; se crearon los servicios antropométricos, con material modernísimo... El Cuerpo de Seguridad recibió un gran impulso. Se aumentó muchísimo y se extendió a todas las capitales y poblaciones importantes»... «Por aquel tiempo fue creada la policía española en Francia...». "La reorganización de la policía comenzaba a dar sus frutos. La criminalidad disminuía... La fotografía, las fichas, las improntas digitales, contribuían a la rápida mejora. Nombré comisiones formadas por los más ilustrados funcionarios conocedores de idiomas y los envié a estudiar la organización y la manera de operar de la policía en París, Londres, Berlín y Roma y puse en relación nuestros centros con los del extranjero, para intercambio de noticias, fichas, señas, etc...» (32)

Las disposiciones sobresalientes en la materia son el Decreto de 9 de septiembre de 1909, reorganizando la policía gubernativa en Madrid; Reales Ordenes de 11 de septiembre de 1907 y 26 de enero de 1908, relativas al reglamento de la Escuela de Policía y a la investigación de los delitos terroristas, y la ley de 27 de febrero de 1908, dando normas para la constitución de la policía gubernativa nacional.

Pero ni una legislación laboral - aunque tímida y balbuciente - ni una policía en consonancia con los nuevos tiempos, libraron a España de profundas convulsiones sociales. Había que auspiciar otras fórmulas más audaces "desde arriba» - auténticas reformas estructurales-para remediar los males endémicos del país.

(32) «Notas de mi vida», pp. 92, 93, 99. 
c) ALGUNOS RASGOS SOBRE EL NIVEL DE VIDA DEL PROLETARIADO EN ESPAÑA EN EL CONTEXTO CRONOLOGICO DE LA SEMANA TRAGICA DE BARCELONA

Acabamos de analizar el "marco legal») de la clase obrera española correspondiente - sincrónico - al estallido de la Semana Trágica de Barcelona. Demos un vistazo a su situación real, manejando unos cuantos datos estadísticos, y comprenderemos (al observar su explotación, marginación y bajo nivel de vida) que los correctivos adecuados no estribaban en tímidas medidas de seguridad y previsión social y laboral, ni en lanzar las tropas a la calle para reprimir todo conato de rebeldía y airada contestación.

Tomemos la fecha de 1905. Los salarios de que se puede disponer suelen estar expresados por día, por jornada de trabajo, cuya duración carecía entonces de tope legal (sólo la de las mujeres y niños tenían el tope máximo de 11 horas, según ley del año 1900). El promedio de horas de trabajo a la semana en la industria textil era de unas 70 , lo que daba una jornada ligeramente superior a las 11 horas, teniendo en cuenta que en 1905 entra en vigor ya la ley de descanso dominical promulgada en el año precedente. (Su estricta observancia, rigurosamente requerida por el gobernador civil de Barcelona, Angel OSSORIO Y GALLARDO, a instancias del ministro de Gobernación, CIERVA, causó al primero no poca animadversión y ello re refleja en la prensa catalana que hemos manejado. Al ser sustituido por CRESPO-AZORIN, se esperaba una mayor flexibilidad en un punto que alli convirtióse en espinoso). En Madrid, según los datos de fuente oficial de la época, el promedio de la jornada oscilaba entre 10 y 11 horas por día; entre 10 y 12 en la edificación y vestido y tocado ( $46 \%$ de la población obrera en Madrid), entre 12 y 14 horas en la panadería, de 11 horas para ferroviarios y tranviarios.

Aunque nos interesa de modo especial la situación del proletariado de Barcelona, no podemos dejar de referirnos, aunque sólo sea brevemente, a la de los mineros de Asturias y Vizcaya y a la problemática de los jornaleros del campo, para después cotejar algunas series de salarios conocidos en Madrid y en Barcelona.

- En las minas de Asturias y Vizcaya, y en la siderurgia, se solía trabajar 10 horas diarias en invierno y 12 en verano, pero comprendiendo en la jornada una hora para comer y descansar a mediodía. (En la huelga general de 1906, la primera petición de los obreros de Vizcaya es la jornada de 9 horas) (33).

En el campo, las jornadas de trabajo estaban determinadas por la duración de la luz solar, variando, por consiguiente, según las estaciones. Las faenas de recolección eran frecuentemente pagadas a destajo. Los 
llamados "criados» o peones fijos de los cortijos y grandes propiedades recibían parte de la remuneración en especie (la comida o una comida al día).

\section{Madrid}

Edificación

Transporte

Vestido $y$ tocado

(la mayoría mujeres)

Alimentación

Metalurgía

Industria del libro y

artes gráficas

Industrias químicas pesetas

al día

$3^{\prime} 50$

$3^{\prime} 40$

2'30

3'20

3'25

3'15

$3^{\prime} 50$ pesetas

a la hora

0'31

0'30

$0^{\prime} 20$

0'29

0'29

0'31

0'30

Los salarios por hora están calculados a base de una jornada de 11 horas, salvo para artes gráficas. Estos promedios no dan idea de la retribución según las calificaciones, por ejemplo en la edificación (construcción) donde el "abanico» o espectro de salarios era ya extenso.

El $30 \%$ de la población asalariada de Madrid estaba formado por mujeres, con un promedio de 2 ' 25 ptas. al día. El $27 \%$ lo estaba por menores de 18 años. El total de asalariados de la industria y el transporte de Madrid ascendía a 97.103. En esta cifra no se incluyen los asalariados del comercio, banca y oficinas.

Recordemos que 1905, en Barcelona, es el año del asalto de elementos militares unitarios al "Cu-cut» y de la cohesión de Solidaridad Catalana. No perdamos de vista que precede a los aranceles proteccionistas del año siguiente, favoreciendo a los patronos de la industria textil.

(33) El gobernador civil de Valencia, en 1909, cuando los sucesos de Julio de Barcelona, era D. Jenaro PEREZ MOSO, que to fue de Oviedo cuando los luctuosos sucesos de Infiesto de 1904, reprimiéndolos con dureza. A ellos alude retrospectivamente El Mercantil Valenciano, en jueves 2 de Septiembre de 1909. Aunque con ocasión de la represión posterior a la Semana Trágica suprimió en la ciudad del Turia el batallón de milicianos voluntarios de la Libertad, la verdad es que no tuvo ningún quebradero de cabeza en esta coyuntura porque blasquistas y sonistas se mantuvieron tranquilos y quietos. 
Barcelona

Oficial de albañilería

Peón de albañil

Carpintero

Costurera

Fundidor metales

Calderero

Impresor tejidos

Hilador

Tejedor en talleres mecánicos

Tejedor en seda

\begin{tabular}{|c|c|}
\hline $\begin{array}{c}\text { pesetas } \\
\text { al día }\end{array}$ & $\begin{array}{l}\text { pesetas } \\
\text { a la hora }\end{array}$ \\
\hline $4^{\prime} 00$ & $0^{\prime} 36$ \\
\hline $2^{\prime} 50$ & $0^{\prime} 22$ \\
\hline $4^{\prime} 00$ & $0^{\prime} 36$ \\
\hline $2^{\prime} 50$ & $0^{\prime} 22$ \\
\hline $4^{\prime} 00$ & $0^{\prime} 36$ \\
\hline $4^{\prime} 00$ & $0^{\prime} 36$ \\
\hline $4^{\prime} 00$ & $0^{\prime} 36$ \\
\hline $5^{\prime} 00$ & $0^{\prime} 45$ \\
\hline $3^{\prime} 46$ & $0^{\prime} 31$ \\
\hline $5^{\prime} 00$ & $0^{\prime} 45$ \\
\hline
\end{tabular}

El promedio de los 144.788 asalariados de Barcelona era, según los datos del Ayuntamiento de la ciudad, de unas 3'75 ptas. por jornada; el promedio del salario femenino (34.333 mujeres), de 2'50 ptas.

Los promedios horarios se han realizado a base de una jornada laboral de 11 horas, habitual en la industria textil, aunque en algunas otras era ligeramente inferior.

Las industrias que mayor número de obreros reunian en Barcelona era la textil algodonera (18.251), la edificación (15.229) y la metalurgía (8.943); el $65 \%$ de la mano de obra en la algodonera era femenino. (La concienciación social de la mujer catalana trabajadora puede deducirse de gran número de testimonios escritos. Recordemos uno relativamente reciente: "La revuelta permanente», de Baltasar PORCEL. Ed. Planeta).

Hasta 1913 carecemos de cálculos de fuente oficial para establecer los índices de coste de vida. Intentaremos aproximarnos al presupuesto mensual de vida de una familia obrera. En Barcelona, los gastos de comida solamente ascendían a 41'70 pesetas por persona al mes.

Reflejaremos seguidamente algunos precios partiendo de los trabajos del Instituto de Reformas Sociales, de algunas indagaciones de MARVAUD y de M. TUÑON DE LARA ( $V$ Variaciones del nivel de vida en España»). Las aportaciones del último, que venimos precisando, nos resultan particularmente valiosas por su claridad y concisión.

Vaca, $1 \mathrm{~kg}$.

Tocino, $1 \mathrm{~kg}$.

Sardinas, $1 \mathrm{~kg}$.

Bacalao, $1 \mathrm{~kg}$.

Arroz, $1 \mathrm{~kg}$.

Judías, $1 \mathrm{~kg}$.

Patatas, $1 \mathrm{~kg}$. $2^{\prime} 60$

$2^{\prime} 20$

1 '05

$1^{\prime} 60$

$0^{\prime} 75$

0 '75

$0^{\prime} 20$
Leche, 1 litro

0 '70

Vino, 1 litro

0 50

Carbón vegetal, $1 \mathrm{~kg}$.

Pan, $1 \mathrm{~kg}$.

Un par de botas

Un par de zapatos

Un traje hombre $0^{\prime} 19$

$15^{\prime} 00$

$10^{\prime} 00$

$14^{\prime} 00$ 
Merluza, $1 \mathrm{~kg}$.

Verduras, $1 \mathrm{~kg}$.

Aceite, 1 litro

Huevos (docena) $1^{\prime} 75$

0 '30

1 '65

$1^{\prime} 15$
Un vestido mujer

Alquiler mensual

de casa obrera

Debe advertirse que en las zonas rurales los precios de los productos agrícolas, lógicamente, eran mucho menores; por ejemplo, 0'87 ptas. el litro de aceite, el kilo de pan $0^{\prime} 25$ y a lo máximo $0^{\prime} 50$, las patatas a $0^{\prime} 10$, los huevos a 0'90, el carbón vegetal a 0'10 y la vivienda (si era alquilada) oscilaba entre 4 y 7 ptas. al mes. El coste de vida era, por tanto, muy inferior al de las ciudades, pero también lo era la calidad de la dieta alimenticia, con ausencia casi total de carnes y pescados, así como todo lo referente a las condiciones de vida.

En cuanto a las "condiciones de trabajo», se trata aún de una época en la cual los locales e instalaciones fabriles carecian, mayoritariamente, de las debidas salubridad, aireación, seguridad, etc. Todavía se encontraban en algunas cuencas mineras cantinas explotadas por capataces (testaferros de las empresas) y tiendas de las mismas empresas en las que obligatoriamente debían comer y abastecerse los obreros (en Vizcaya se logró su abolición después de la huelga de 1903). Hasta mayo de 1906 no comenzó a funcionar la Inspección del Trabajo en fábricas y talleres.

Por otro lado, los ritmos de trabajo eran lentos y en ninguna parte se aplicaban los métodos llamados luego, con dudosa acepción, de «racionalización». En los núcleos urbanos, la distancia ente el domicilio y el lugar del trabajo, solían ser cortas y apenas alargaban la jornada. Otra cosa distinta era en el campo, donde, además, existía el problema del destajo en las recolecciones.

En la "calidad de vida» no debemos dejar de considerar las malas condiciones de la vivienda. En las grandes ciudades, como Madrid, predominaban en los barrios obreros las llamadas "casas de corredor" con escasas o nulas condiciones higiénicas. La vivienda rural era muy heterogénea, con el problema de cientos de miles de casas de adobe, donde se vivía en un régimen de promiscuidad de hombres y bestias, carentes de luz eléctrica, de agua, etc. En las ciudades la insalubridad no era infrecuente, todavía existian muchas viviendas obreras sin alumbrado eléctrico, agua corriente, inodoros...

Se vivía en un período en que los servicios públicos de Sanidad y Enseñanza resultaban a todas luces insuficientes. Las 24.000 escuelas públicas, mal dotadas, quedaban muy cortas para las necesidades reales. A pesar de la abundancia de escuelas privadas, el número de niños de familias trabajadoras que estaban empleados en penosos menesteres 
laborales era alarmante, convirtiendo en papel mojado la obligatoriedad de la enseñanza entre los seis y los doce años. (En este contexto de insuficiencia de puestos escolares, se comprenden las quejas, que más atrás expusimos, de CAMBÓ en carta a LA CIERVA por el cierre decretado en Barcelona, tras los sucesos de julio de 1909, por el nuevo gobernador CRESPO-AZORIN, de las escuelas laicas, en el caso de las que no se dedicaran a divulgar enseñanzas disolventes contra el "sistema».)

Vamos a fijarnos a continuación en el año 1914, sobre el que acabará repercutiendo la Primera Guerra Mundial, y que es antesala del descontento que precedió al estallido de la crisis española de 1917.

Efectivamente, 1914 es la fecha en que la evolución económica no sufre hasta en sus últimos meses el impacto que había de ser decisivo de la Primera Gran Guerra. Por otra parte, es el momento inicial en que se puede disponer de estadísticas de salarios, índices de precios y coste de vida, con las reservas y limitaciones que merecen este género de datos en España.

En 1914, según el discutible procedimiento de computar las declaraciones de profesión en las cédulas personales, había en España 1.113 .839 obreros, de los cuales el $13^{\prime} 72 \%$ trabajaban una jornada de 8 horas y el $76 \%$ trabajaban jornadas de 10 o más horas. En la cifra citada no estaban incluidos los asalariados agrícolas, los empleados y el servicio doméstico.

El promedio semanal del salario del obrero español en 1914, era de casi 25 ptas., (24'90). Otros promedios más interesantes son los del salario-hora de obreros calificados $\left(0^{\prime} 43\right.$ ptas.), de peones $\left(0^{\prime} 29\right)$, de mujeres $\left(0^{\prime} 17\right)$ aún tratándose de las que tenían trabajo calificado. En las minas asturianas el promedio de salarios en el fondo era de $5^{\prime} 17$ ptas. al día por jornada de 9 horas, y de 4'08 para los obreros del exterior.

Otros promedios representativos de salarios-hora de obreros calificados son los de las capitales importantes: Madrid, 0'60; Barcelona, 0'54; Valencia, 0'45; Sevilla, 0'47; La Coruña, 0'50: Guipuzcoa, 0'50: Vizcaya, 0'45; Asturias, 0'48, que contrastan con 0'37 en Castilla la Nueva y 0'35 en Extremadura.

Las "condiciones de trabajo» solamente experimentan muy ligeras variaciones. Hubo, no obstante, dos leyes de jornada máxima de trabajo: la de 1910, estableciéndose en 9 horas para los mineros de fondo, $y$ la de 1913, fijando en 60 horas semanales la de la industria textil. Se estableció también la llamada "ley de la silla» (1912), que obligaba a proporcionar asiento a las mujeres trabajadoras. En parte estas disposiciones se debieron a CANALEJAS. (La incidencia del Instituto Nacional de Previsión, creado por CIERVA en 1908, en el «standard» de vida de 
los trabajadores, no se hacía notar de manera particularmente positiva y ostensible).

Vamos a echar un vistazo a la evolución de algunos precios de artículos alimenticios en Madrid. Se trata de datos de 1913, publicados por España Nueva, de Madrid, en 1917.

$\begin{array}{llll}\text { Aceite } & \text { 1'21 ptas. litro } & \text { Jabón } & 0^{\prime} 78 \text { ptas. kilo } \\ \text { Arroz } & 0^{\prime} 45 \text { ptas. kilo } & \text { Sardinas aceite } & \text { 1'47 ptas. kilo } \\ \text { Bacalao } & 1^{\prime} 23 \text { ptas. kilo } & \text { Tocino } & \text { 2'10 ptas. kilo } \\ \text { Judias } & 0^{\prime} 67 \text { ptas. kilo } & & \end{array}$

Demos ahora una ojeada a los gastos de la ración alimenticia diaria de una familia obrera valenciana en 1914, según un estudio de GONZALEZ COLMENARES. Las necesidades de "despensa» erosionaban enormemente el salario.

$\begin{array}{lllr}\text { Pan } & 0^{\prime} 60 \text { ptas. } & \text { Bacalao } & 0^{\prime} 30 \text { ptas. } \\ \text { Carne } & 0^{\prime} 25 \text { ptas. } & \text { Arroz } & 0^{\prime} 12 \text { ptas. } \\ \text { Aceite } & 0^{\prime} 17 \text { ptas. } & \text { Verduras } & \text { precio insignificante }\end{array}$

Analizamos otro repertorio de precios, en 1914, publicado por EI Correo Catalán, en $1^{\circ}$ de enero de 1918:

$\begin{array}{llll}\text { Bacalao } & \text { 1'50 ptas. kilo } & \text { Patatas } & 0^{\prime} 10 \text { ptas. kilo } \\ \text { Judias } & 0^{\prime} 62 \text { ptas. kilo } & \text { Aceite } & 1^{\prime} 14 \text { ptas. kilo }\end{array}$

(Habría que dudar sobre si lo precios están tomados al por mayor, porque el de las patatas $-y$ otros - están por debajo de la media).

Más completos son los precios para estudiar el coste de la vida - referidos a 1913- que elaboró la Sociedad Obrera de Montilla (Córdoba):

$\begin{array}{llll}\text { Pan } & 0^{\prime} 30 \text { ptas. kilo } & \text { Carne de cerdo } & 3^{\prime} 00 \text { ptas. kilo } \\ \text { Judias } & 0^{\prime} 30 \text { ptas. kilo } & \text { Carbón } & 0^{\prime} 15 \text { ptas. kilo } \\ \text { Arroz } & 0^{\prime} 45 \text { ptas. kilo } & \text { Aceite } & 0^{\prime} 25 \text { ptas. kilo }\end{array}$

Es conveniente recordar el precio del pan (atendiendo a promedios nacionales) para los años 1913, 1914, 1916 y 1920 que se fija, respectivamente en: 0'39 ptas. el kilo, 0'44, 0'51 y $0^{\prime} 66$.

Esto nos conduce a subrayar la descomunal carrera ascensionista de los precios que se produce a partir de 1915, sin cuyo conocimiento cabal resultan incomprensibles muchos fenómenos de la vida española de aquel entonces (su proyección sobre el aumento «in crescendo" del número de huelgas anuales; la sindicación de los oficiales en las Juntas Militares de Defensa, a impulso del coronel B. MARQUEZ: las Juntas Civiles de Funcionarios de los Cuerpos de Correos y Telégrafos y, en úl- 
tima instancia, toda la problemática de la crisis del 17).

El índice oficial de precios al por mayor en España, tomando como base 100 el año 1913, experimentó la evolución que sigue:

Hagamos la advertencia de que se trata de un índice simple.

A esta subida astronómica, consecuencia de la Guerra Mundial (que produjo pingües ganancias a empresas y especuladores) hay que añadir la escasez o rareza de productos en muchos mercados locales; debieron proliferar la ocultación, el contrabando, el «mercado negro». Este alza revistió caracteres alarmantes en los productos alimenticios durante los primeros meses de 1915. La revista España, del 5 de marzo de ese mismo año, daba cuenta a sus lectores de los porcentajes de la inflación a raíz de 1914. La Guerra, al repercutir en nuestro país, supuso «beneficios extraordinarios» para la burguesía triguera castellana (o aristocracia absentista, igualmente, cerealícola), para la burguesía vasca dedicada a los negocios mineros y siderometalurgicos y para la textil catalana. Frente a ello destaca la "carestía» (auténtica crisis de subsistencias) que ocasionó a los proletarios y a los estratos más modestos de la clase media, que vivían de rentas salariales o ingresos fijos. De este modo, la crisis bélica acentuó la polarización de nuestro cuerpo social, haciendo más hirientes los contrastes.

\section{d) LA REPRESION VISTA DESDE VALENCIA Y}

\section{LA INHIBICION DE LOS REPUBLICANOS VALENCIANOS ANTE LA REVOLUCION SOCIAL}

La no adhesión de Valencia ante la huelga general proclamada para el 2 de agosto; su calma durante la Semana Trágica, fue comentada en Madrid por El País. Inmediatamente las acusaciones, que iban veladas entre líneas, fueron recogidas por El Mercantil Valenciano (34).

(34) "Juicios", art. aparecido en "El Mercantil Valenciano», martes 31 de Agosto de 1909, donde también puede leerse:

"El jefe político de Valencia, que no otra cosa es por sus hechos, procederes y desplantes, el gobernador Pérez Moso, además de denunciar y recoger periódicos, multar a todo bicho viviente y tenérselas tiesas con los enemigos del orden, ha tenido la luminosa y rejuvenecedora idea de desarmar la milicia veterana de la ciudad del Turia". Hay que recapacitar sobre la Memoria del Fiscal del Tribunal Supremo, Sr. UGARTE, sobre la Semana Trágica, donde se habla de la ayuda en Cataluña de los somatenes a los insurrectos. Pero al parecer este no fue el caso de Valencia. 
Se reprochaba a los blasquistas su falta de espíritu solidario para con sus hermanos de Cataluña (los republicanos). Precisamente, cuando SALMERON y CAMBÓ trataron de ampliar el marco geográfico de Solidaridad Catalana y visitaron Valencia con el propósito de ganar adeptos para su causa, tropezaron con la viva incomprensión de Unión Republicana. La propaganda antisolidaria fue llevada a término desde EI Pueblo por Félix AZZATI, su director (auténtico «delfín» de BLASCO IBAÑEZ). Los sorianistas -más por estrategia política que por convicción ideológica - se mostraron prosolidarios, teniendo como portavoz a $E I$ Radical y a Rodrigo Soriano. Blasquistas y sorianistas andaban a tiros por las calles de la ciudad del Turia. El Mercantil Valenciano, aunque de tendencia igualmente republicana, trataba de salvaguardar su independencia en aquella coyuntura, to que le haría acreedor de las especies reprobatorias de LERROUX (35).

Recordemos aquí brevemente que los aranceles proteccionistas de 1906 adoptados por MORET (favorables a la burguesía vasca, implicada en la minería y siderometalurgia y a la catalana, dedicada a la actividad textil) perjudicaban notablemente a los productores y exportadores citrícolas valencianos (beneficiando, en cambio, a los arroceros). Esto hizo que, de alguna manera, la burguesía "taronjera», sin el grado de concienciación autonomista de la del Principado, hiciese patente su inconformismo ante el Poder Central. Fueron sus canales de expresión la «Federación Agrícola de Levante» y la Alta Cámara. En el Senado, a fines de enero de 1908, los próceres valencianos con NAVARRO REVERTER a la. cabeza, consumieron sendos turnos para debatir el problema de la crisis naranjera (36).

Estos terratenientes, cuando se produjo la visita indicada de SALMERON, CAMBÓ y otros catalanistas sufrieron un «auténtico trauma de identidad". Por un lado hablaron de intereses económicos contrapuestos entre Cataluña - industrial - y Valencia - agrícola-, coincidiendo en este presupuesto programático con los blasquistas, sus antípodas, quienes se dedicaron a abuchear al líder de la Liga en sus intervenciones públicas. Por otro, veían, en una posible conjunción con Solidaridad Catalana el medio de intimidar a Madrid.

La Exposición Regional hizo olvidar el estado real de un valencianismo político sin cohesión, dividido por intereses antagónicos a nivel infra y supra-estructural. Fue promotor de aquella D. Tomás TRENOR, Presi-

(35) «Mis memorias», pág. 521. Ed. Afrodisio Aguado.

(36) "Las Provincias", lunes 27 de Enero de 1908. NAVARRO REVERTER, notable abogado, estuvo muy ligado al más importante capitalista de Levante, el marqués de CAMPO, antiguo propietario de este periódico, antes de que lo dirigiera Teodoro LLORENTE. 
dente del Ateneo Mercantil (luego Marqués del Turia). De alguna manera sirvió de desagravio de la clase propietaria citricola (37). EI P. VICENT había conseguido que proliferaran en este "habitat rural» los sindicatos católicos, que algunos historidores califican de amarillos. La rebeldía por la política arancelaria fue en Valencia efímera. Quedó enterrada en cuanto el Ministro de Fomento del Gabinete MAURA, GONZALEZ BESADA hizo unas cuantas promesas: creación de un puerto naranjero en Burriana, conciusión de las obras del ferrocarril directo Madrid-Valencia por Cuenca, abaratamiento de las tarifas férreas para facilitar el transporte interior de los cítricos... etc.

Valencia en la etapa 1907-1909 había sido un motivo constante de preocupación para el ministro Cierva: huelga de consumeros y vendedores del mercado a la que respondió con la declaración del estado de sitio. Introducción por la fuerza de las armas del arzobispo Victoriano GUISASSOLA, expulsado por los blasquistas. Huelga de los estudiantes de Medicina, disconformes con la escasa asignación otorgada al Ministerio de Instrucción Pública (del cual era delegado en Valencia D. Enrique SERRANO MORALES); la solidaridad con Melquiades ALVAREZ le costó al Dr. MOLINER y a su hijo encierro en la cárcel, acusados de inducir a los alumnos revoltosos que, a su vez abuchearon al Rector de la Universidad Sr. MACHI. Estallido de petardos en los mingitorios públicos y hasta en el Camarín de la Basílica de la Virgen de los Desamparados. Al mismo tiempo, en las ramblas barcelonesas explotaban bombas, de fabricación doméstica, colocadas por Juan RULL (desenmascarado por el detective inglés contratado para el caso $\mathrm{Mr}$. ARROW). En el Congreso se afirmó que «Valencia se había convertido en una sucursal de Barcelona».

Sin embargo, en julio de 1909, en Valencia reinó una paz absoluta. No ocurrió lo mismo en Alcoy, núcleo fabril, donde los sucesos fueron de

(37) La aristocracia valenciana, (y la burguesía terrateniente vinculada a ella por lazos de consanguineidad y mimetismo en mentalidad social y formas de vida), se vieron muy complacidas ya en Julio de 1907 con motivo de la llegada a Valencia de la infanta $D^{a}$ Isabel (tía de Alfonso XIII) para presidir los festejos de la Feria. La justa poética de aquel año estuvo mantenida por el Padre Luis CALPENA. Vid. "Las Provincias», martes 23 de Julio de 1907; domingo 28, viernes 2 de Agosto; domingo, 4.

- A propósito del cable tendido con Madrid, merced a la Exposición Regional, afirma El Mercantil Valenciano: "Temor e ingratitud indica el acto del Sr. Pérez Moso. Temor a que se utilicen las armas del batallón e ingratitud para con los revolucionarios de Valencia. Sea por lo que fuere, por respeto a la Exposición, por los intereses creados (de los blasquistas) tras tantos años de mayoría municipal, por lo que sea, ello es que Valencia, estando quieta desde el 26 de Julio al 2 de Agosto, ha prestado un servicio imponderable al gobierno constituido y a la causa del orden". Ibidem, nota 34 . 
consideración (38). Nos encontramos ante una manifestación más del consabido fenómeno de la ururalización del País Valenciano», advertido ya por BLASCO IBAÑEZ cuando definió a Valencia como «huerta con ciudad» y que tampoco pasó desapercibido a «AZORIN» en su época de mal estudiante en ella.

En 1909 faltaba en Valencia, para secundar con brío una revolución social, un elevado contingente humano dedicado a la actividad industrial en régimen de concentración, y captado por la causa socialista (el número de afiliados era entonces muy exiguo). Una masa campesina, sin existir ni el más mínimo conato de alboroto del orden público en la capital, poco podía hacer. Radicales y blasquistas agrupaban a las clases medias urbanas. A pesar de su verborrea demagógica y anticlerical (que como observa T. DE LARA en el fondo consistía en una maniobra de distracción de las masas), sus jefes - BLASCO IBANNEZ y Rodrigo SORIANO - eran acaudalados burgueses y sus electores y afiliados de extracción social sotoburguesa y mesocrática, pero no proletaria. Conforme se vayan consolidando el socialismo y su central sindical, U.G.T., la Unión Republicana (luego el P.U.R.A., Partido de Unión Republicana Autonomista) verá retroceder su clientela y sentirá a sus pies el abismo de carecer de una plataforma auténticamente popular, obrera. Esto explica las posteriores piruetas políticas de AZZATI para, por pura táctica, aparentar que quedaban canceladas anteriores veleidades procentralistas y se abrazaba la causa del autonomismo. En el fondo, si LERROUX frenó en Barcelona la marcha ascendente del catalanismo, sirviendo a los intereses de Madrid, BLASCO y AZZATI capitanearon en Valencia, igualmente un partido sucursalista, dócil a las directrices del Poder Central. Hemos de subrayar que en 1917 fue precisamente la actitud del P.U.R.A., y más concretamente de su jefe AZZATI, la que hizo estallar - y así nos lo refiere Manuel CORDERO - contra el parecer del propio Pablo IGLESIAS, la huelga ferroviaria de Valencia, anticipándose a la general de agosto, y dando un motivo justificado para que se desencadenase la reacción. Una vez más hicieron el juego al gobierno de turno de Madrid, contrariando las consignas de U.G.T. y los socialistas y atentando contra los intereses de la clase obrera.

Advirtamos que esta domesticación de los partidos de izquierda fue más nociva casi que la de los de derecha. Al fin y al cabo resulta coherente y lógico que Teodoro LLORENTE y sus seguidores de "Lo Rat Penat" y Las Provincias se sintieran complacidos en 1907-9 con MAURA y

(38) El Mercantil Valenciano, "De Alcoy», 26 de julio en miércoles 28; "De Alcoy», 28 de Julio en viernes 30; "Lo que pasa en Reus y Alcoy», relato oficial, 29 de Julio de 1909). 
CIERVA en el poder, defendiendo su ideología e intereses. No podemos afirmar otro tanto de la conducta de BLASCO y los suyos en julio de 1909, contra cuya incongruencia arremetieron El País y El Mercantil Valenciano, calificándolos de cobardes y traidores, coincidiendo en los apelativos con Pablo IGLESIAS.

"De Valencia se pudo enviar fuerzas a Barcelona sin riesgo alguno; en Valencia no ha habido huelga, $y$ tal ha sido su corrección que no se han hecho alli detenciones. Ni un detenido que sepamos ha habido en la provincia de Valencia, cuando tantos han sido en Madrid, Alicante, Asturias, Rioja, Vizcaya...

Es incomprensible por esto que se disuelva el batallón de milicianos de Valencia.

$\mathrm{Ni}$ es justo eso, ni que alcance a esa y a todas las provincias que han permanecido tranquilas la suspensión de las garantías constitucionales. No es que lloremos la disolución y desarme del batallón; es que nos parece inaudito que abuse el Sr. Pérez Moso (gobernador civil de Valencia) de una autoridad de la cual no tuvo que hacer uso en días difíciles").

La respuesta de El Mercantil Valenciano, a los párrafos arriba transcritos, apareció en jueves, 2 de septiembre de 1909 con el título "Las bromas de El País":

"Hay exégetas que aseguran muy formalmente que nuestro colega $E I$ País está de broma hace algunos días y que broma fue el artículo que reprodujimos...

(...) Será broma, pura broma; pero broma en que tienen mucho que aprender los republicanos, que sepan que las revoluciones no se improvisan, que las revoluciones necesitan una organización previa, que las revoluciones necesitan caudillos, verdaderos caudillos... En cuanto a EI Mercantil Valenciano no blasona de revolucionario, ni a título de revolucionario dirige un partido formidable, ni está a las maduras de la política llamada revolucionaria. $Y$ no tiene detrás de sí masas, ni tiene inmunidades, ni explota el nombre de la Revolución, y por consiguiente huelgan ciertas alusiones, y huelgan tanto más porque puede demostrar y demostrará en sazón oportuna, que no se ha negado jamás a contribuir con todas sus fuerzas al triunfo de la causa republicana... Como demostrará otras cosas que hoy no puede ni mentary.

Se ensaña, de manera especial, contra «Unión Republicana», cuyos parlamentarios gozaban de la correspondiente inmunidad, razón por la que no podían ser procesados sin los correspondientes suplicatorios a las Cortes. El comentarista no podía ser más explícito por estar vigente la censura gubernamental, al quedar en supuesto las garantías constitucionales, medida que con la cautela lógica, fue presentada como impopular en su día, por el propio Mercantil Valenciano en el artículo titulado 
«¡Chitón!» (jueves, 29 de Julio de 1909). Quizás las reprobaciones más acertadas hacia los blasquistas se contengan en las siguientes frases:

«Eso será una broma, pero es verdad. Verdad que demuestra de manera aplastante muchas cosas que en su día se discutirán. Verdad que demuestra la inmensa diferencia que existe entre los revolucionarios de ley y los revolucionarios verbalistas. Verdad que enseña que no es lo mismo predicar que dar trigo, ni aceptar cargos o conquistarlos en fuerza de blasonar de revolucionarios que tener riñones y estar intelectualmente a la altura de esos cargos, ni que tener condiciones para organizar y poner las obras a la altura de las vocinglerías de los retóricos de la Revolución» (39).

He aqui una de las muchas críticas adversas que ha suscitado el comportamiento de los intelectuales burgueses o pequeño-burgueses, acusados de individualismo y desconexión entre sus teorías y su praxis. BLASCO IBANNEZ, dedicado por entonces a la creación literaria, aunque diputado por Valencia (quedó en tercer puesto en las legislativas de 1907, obteniendo el primero R. SORIANOI, se había convertido en un político nominal, renunciando a toda «acción». Su compromiso había pasado a ser puro convencionalismo y sus ingresos aumentaban en progresión creciente.

\section{e) HILO DE CONTINUIDAD ENTRE LA REVOLUCION SOCIAL DE 1909 Y LAS CRISIS DE 1898 Y 1917.}

Podemos concluir estas aportaciones sobre la reacción posterior a la Semana Tráfica, afirmando que 1909 supone la primera eclosión ubversiva del siglo $X X$ (primer ensayo revolucionario durante el reinado de Alfonso XIII), antesala de 1911-12 e igualmente pórtico de la crisis de 1917. Tras la tercera de las fechas expresadas, la Monarquía quedó definitivamente hipotecada al Ejército y sentenciada de muerte. De nada sirvió el paréntesis de PRIMO DE RIVERA. Pudo MAURA, en 1909 y más tarde con ocasión de la solicitud que le hicieron las Juntas Militares de Defensa en el verano de 1917, antes de la formación del Gobierno Nacional de 1918, haber dado un golpe de Estado y haberse anticipado a D. Miguel y a MUSSOLINI (40). Respetuoso con la Constitución y el Rey no quiso hacerlo. Cronológicamente la crisis de 1909 se sitúa entre la de 1898 (dejemos ahora la de 1911-12 con CANALEJAS) y la de 1917.

De la primera difiere por su contexto ideológico, mucho menos pro-

(39) «Las brómas de El País». En El Mercantil Valenciano, 2 de Septiembre de 1909.

(40) PABON, J. "Cambó...», t. I, p. 353. 
fundo (aunque asome la veta "regeneracionista») y por sus consecuencias. El descalabro del Barranco del Lobo no puede ni remotamente compararse con la pérdida de las colonias ultramarinas. Aquella produjo literatos como A. MACHADO, «AZORIN», BAROJA, VALLE-INCLAN, UNAMUNO... O sociólogos como J. COSTA, ISERN, Macias PICAVE$A$, Lucas MALLADA (aunque ingeniero de minas). Testigos presenciales de los hechos de 1909 fueron el eximio poeta catalán Joan MARAGALL y Gumersindo de AZCARATE que por entonces lleva a cabo, como venimos repitiendo, una fecunda tarea al frente del Instituto de Reformas Sociales. Parece como si en este "climax» de catastrofismo nacional, de dislaceración del cuerpo social entero, en situaciones en suma hiperestésicas, floreciesen mejor la agudeza, el ingenio, la creatividad estética. Es lo cierto que el afán de «renovación» existente en ciertos sectores de nuestra «intelligentsia» (anterior a ambas crisis, la de 1898 y la de 1909) y los subsiguientes procesos de introspección y revisionismo, dan sazonados frutos al ser expresados en categorías literarias, filosóficas o sociológicas, éstas ya puramente empíricas.

Igualmente, 1909 guarda similitudes y asemejanzas con la segunda. Efectivamente, la crisis de 1917, con su especifico triple aspecto (huelga general revolucionaria de Agosto, asamblea de parlamentarios catalanes de 5 de Julio y Juntas Militares de Defensa), se aproxima a la de 1898 y 1909 por un mismo deseo de «salvación nacional» (lo que les da unidad a pesar del polimorfismo expresadol. Tanto en 1909 como en 1917 se rompe la pacífica convivencia entre las clases sociales del país. El cuerpo social aparece en uno y otro caso gravemente enfermo.

En el movimiento de 1917 las responsabilidades quedaron claras: recayeron sobre las Juntas Militares de Defensa y muy particularmente sobre su inspirador, Benito MARQUEZ, la burguesia catalana - que encarnó "la revuelta de los privilegiados»- $y$ los dirigentes de las masas obreras (LARGO CABALLERO, Julián BESTEIRO, ANGUIANO y SABORIT). Por el contrario, quedan difusas en 1909. Son muchos los que hasta la fecha se han complacido en presentar los sucesos de julio de 1909 como casuísticos, entre ellos el propio OSSORIO en un dictamen emitido sobre el particular (41).

No cabe duda de que, al menos en lo que atañe a la huelga general, hubo preparación, tanto en 1909 como en 1917. Pero en 1917 los socialistas vieron aumentado su peso específico, dándose en la base un mayor número de afiliados y grado de concienciación y, en los jefes, una planificación mucho más acabada y minuciosa. Por otro lado, las clases medias españolas que en 1909, en Barcelona, tuvieron deseos de "gubernamentarse» y regresar al orden (CAMBO), en 1917 perdieron el miedo a la revolución ( $y$ a la reacción) y ante la terrible carestía suscita- 
da por la guerra del 14, cobraron sentido corporativo hasta los militares de carrera - mesocracia, al fin y al cabo-. También los funcionarios de Telégrafos y Correos (Juntas Civiles). El afán de sindicación recorrió nuestra piel de toro como un auténtico ciclón. Esta sensibilización para defender intereses comunes no era tan fuerte en 1909. En ambos casos - 1909 y 1917 - el proletariado, erguido como fuerza coherente e insurgente, deseó con vehemencia mejorar su nivel de vida y una participación activa en la política nacional. Para ello intentó desarticular los oxidados engranajes de la maquinaria canovista, pero sin conseguirlo, pues acabó siendo abandonado una y otra vez a sus solas fuerzas.

En 1917 el Ejército prevaricó de sus aspiraciones reformistas - contiendas en el, el Manifiesto del $1^{\circ}$ de Junio de las Juntas Militares de Defensa - para llevar a cabo la ureacción», esto es, la represión de los sucesos de agosto, como brazo armado del Gobierno. (De igual manera procedió en 1909, siendo juzgado FERRER GUARDIA por un Tribunal Militar por estar en vigor el estado de sitio y la Ley de Jurisdicciones de MORET). La burguesía catalana - que en la última semana de Julio de 1909, ante la quema de conventos, manifestó un "no es esto» por boca del senador GOMAR - , después del verano de 1917 dio un giro aún mucho más acusado a la derecha $y$ entregó a dos de sus miembros como ministros del gobierno de concentración presidido por el Marqués de ALHUCEMAS (GARCIA PRIETO): las jóvenes promesas de la Liga y la Esquerra respectivamente, VENTOSA y RODES.

En 1909 y en 1917 la energía (o si se prefiere, la dureza) de la clase política española de derechas estuvo encarnada por LA CIERVA: ministro de la Gobernación entonces. Al frente de la Cartera de Guerra después de la crisis del 17 (sobre la que se proyectará en OctubreNovimebre la revolución rusa), apoyado por las Juntas Militares de Defensa; a su lado GARCIA PRIETO resultaba una figura gris y secundaria. Así lo entendió el coplero de turno:

(41) Angel OSSORIO Y GALLARDO. "Declaración de un testigo», opina asi: "Hay que distinguir dos casas: la huelga general, cosa preparada y conocida, y el movimiento anárquico revolucionario, de carácter político, cosa que surgió sin preparación... En Barcelona la revolución no se prepara, por la sencilla razón de que está preparada siempre». De este modo minimizaba su responsabilidad como gobernador civil.

- Por su parte, el veterano anarquista Anselmo LORENZO escribió: "Lo que está ocurriendo aqui es sorprendente. En Barcelona ha estallado una revolución social y ha sido iniciada por el mismo pueblo. Nadie la ha instigado. Ni liberales, ni nacionalistas catalanes, ni republicanos, ni socialistas ni anarquistas"). (Carta a Tárrida del Mármol, 13 de Julio de 1909). 


\author{
«Ni Prieto es Presidente \\ ni tal rảngo conserva... \\ García es simplemente, \\ García el asistente \\ del general La Cierva». (42)
}

En cambio, cuando la crisis de 1911-12, la situación es distinta. Fijémonos en la huelga general ferroviaria de 12, los sindicatos del ramo podrán competir en esta esfera concreta, con las decisiones del poder (ya han llegado a ser un contra-poder). CANALEJAS, admirador del francés Arístides BRIAND - hombre de izquierdas, pero de medidas drásticas cuando estaba al frente de un Gobierno- creyó que todo se resolvería siguiendo su ejemplo y decretó la movilización de 12.000 huelguistas, que, según su cartilla militar, se hallaban en situación de primera reserva. Tuvo que pactar y transigir.

El temperamento de LA CIERVA era incompatible con todo intento de negociación y transacción, y ello, por paradójico que parezca vino a constituir su mayor defecto y su mayor virtud. Aquí estriba la clave de su personalidad y de la impronta que la misma dejó en el decurso histórico de los acontecimientos hoy tratados. (43)

(42) Cierva después de la crisis de 1917 disolvió las Juntas Civiles (Correos y Telégrafos) y las Militares de Sub-oficiales y clases de Tropa, en tanto que, para halagar a los Oficiales de las Juntas que creara BENITO MAROUEZ, llevó a La Gaceta las reformas pretendidas por éstos, concediéndolas por decreto y sustrayéndolas al Parlamento.

(43) No solamente LA CIERVA carecía de ductilidad. En líneas generales esta cualidad le faltaba a escala individual y global a toda la derecha española (y aún hoy, es menos flexible que la europea, por causas de retraso histórico - cambios de infraestructura - que comportan ritmos lentos en los cambios de mentalidad o supraestructura). He aquí el modo en que enjuicia los fenómenos de 1909 el primogénito de D. Antonio MAURA. Nada de concesiones:

"Se hundió la Corona porque colocada desde 1909 en la disyuntiva de enfrentarse con sus irreconciliables enemigos hasta vencerlos o sojuzgarlos, o contemporizar con la revolución, entregando uno tras otro, para aplacarles temporalmente, los reductos que defienden el Poder público, optó por este último término... La primera de sus capitulaciones (de la Corona, que ya sabemos que debe ser un Poder Moderador) en el orden cronológico, consistió en haberse allanado al «Maura no». ("Recuerdos de mi vida», 1934. El subrayado es nuestro). 


\section{FUENTES HEMEROGRAFICAS}

- Las que se citan en el texto, en lo referente a diarios y prensa periódica de Madrid y capitales de provincias, sobre todo.

- "Diario de Sesiones de las Cortes». Congreso y Senado.

- Fundamentalmente: «La Gaceta de Madrid». Enero de 1907 a octubre de 1909.

\section{BIBLIOGRAFIA}

(1) AUNOS, Eduardo. «Itinerario histórico de la España Contemporánea». Ed. Bosch. Barcelona, 1940.

- «España en crisis (1874-1936)». Librería del Colegio. Buenos Aires, 1942.

(2) "AZORIN» (MARTINEZ RUIZ, José). "La Cierva». Guadalajara, 1910.

- "La obra de un ministro" y "Un discurso de la Cierva». Ambos trabajos en O. C. t. Ill. Ed. Aguilar.

(3) DOLLEANS, Edouard. "Historia del movimiento obrero", t. II (1871-1920). Ed. Zero. ZYX. Madrid, 1969.

(4) FERNANDEZ ALMAGRO, Melchor. "Historia política del reinado de Alfonso XIII». Ed. Montaner y Simón. Barcelona, 1936.

(5) GARCIA VENERO, M. "Historia de los movimientos sindicalistas españoles (1840-1925)». Editora Nacional. Madrid, 1961.

(6) INSTITUTO DE CULTURA HISPANICA. "La población activa española de 1900 a 1957»). Madrid, 1957.

(7) INSTITUTO NACIONAL DE ESTADISTICA. «Principales actividades de la vida española de la primera mitad del siglo XX». Madrid, 1951.

(8) INSTITUTO DE REFORMAS SOCIALES; «Estadística de huelgas. Memorias de 1917-1921, 1920-21». No nos sirve para 1909; si para verificar evolución posterior.

(9) INSTITUTO DE REFORMAS SOCIALES. ANONIMO. «El problema agrario en el mediodía de España, conclusiones para armonizar los intereses de propietarios y obreros; medio de aumentar la producción del suelo». Publicado por el I.R.S. con el título: «Memoria que la comisión nombrada para adjudicar el premio concedido por S.M. el Rey presenta al Instituto de Reformas Sociales de Madrid». Madrid, 1904. Incluido en "Las agitaciones campesinas andaluzas», de J. DIAZ DEL MORAL.

(10) JUTGLAR, Antonio, "En torno a la condición obrera en Barcelona entre 1900 y 1920. En Estudios de Sociologia, n 1. Barcelona, 1966.

- "Els burgesos catalans». Barcelona. Ed. Norfeu, 1966.

(11) MADARIAGA, Salvador de. «España. Ensayo de Historia Contemporánea». Ed. Hermes. México. Buenos Aires, $6^{\text {a }}$ ed., 1955. Y MARVAUD, "La question sociale en Espagne»: París, 1910.

(12) MINISTERIO DE TRABAJO. "Estadística de salarios y jornales de trabajo». (1914-1930)». Madrid, 1931.

(13) OSSORIO Y GALLARDO, Angel. «Mis Memorias». Ed. Losada. Buenos Aires, 1961.

(14) PEIRATS, J. «Los anarquistas y la crisis politica española». Ed. Alfa. Buenos Aires, 1964.

(15) ROMEU ALFARO, Fernanda. «Las clases obreras en España durante el primer tercio de siglo XX (1898-1930)». 2 vols. 1966.

(16) SOLA, Pere. "Las escuelas racionalistas en Cataluña, 1909-1939». Tusquets. Barcelona, 1976.

(17) TUÑON DE LARA, M. «Introducción a la Historia del Movimiento Obrero». Nova Terra. Barcelona, 1966 y tambièn MARVAUD, "L'Espagne an XXe siècle», París, 1913.

(18) VALDOUR, "La vie ouvrière. L'onvrier espagnol». Lille, 1919, 2 vols. 